\title{
Psychobiology, Psychiatry, and Psychoanalysis: The Intersecting Careers of Adolf Meyer, Phyllis Greenacre, and Curt Richter
}

\author{
ANDREW SCULL and JAY SCHULKIN*
}

\section{Introduction}

By common consent, Adolf Meyer (1866-1950) was the most prominent and influential American psychiatrist of the first half of the twentieth century. Particularly after his appointment to Johns Hopkins, as its first professor of psychiatry, he dominated psychiatry in the United States until his retirement in $1941 .^{1}$ But his influence was almost equally strong in Britain, where his pragmatism and therapeutic eclecticism had a wide appeal. $^{2}$

In this paper, we examine some central aspects of Meyer's life and work, and focus particularly on his role as a mentor and patron of the research and careers of two other major figures in twentieth-century psychiatry and psychobiology, broadly conceived. The first of these, Phyllis Greenacre (1894-1989), worked closely with Meyer from 1916, when she graduated from Chicago Rush medical school and joined his staff at Hopkins, till her abrupt departure from Baltimore in late 1927. For the next decade, Meyer continued to play an important role in her life and career, though to his dismay she was now progressively abandoning his distinctive type of psychiatry for psychoanalysis. Completing that process of intellectual transition just as Freud's followers were moving to a position of institutional and theoretical dominance in American psychiatry, Greenacre rose to remarkable prominence in those circles, one of the few non-refugee analysts to become part of the psychoanalytic elite.

Curt Richter (1894-1988) was still another promising young scientist attracted to Meyer's circle, initially through a decision to move from Harvard to Johns Hopkins to work with the founder of behaviourist psychology, John B Watson. With Watson's resignation from the Hopkins faculty in the aftermath of a sex scandal, Meyer orchestrated Richter's succession to head the psychological laboratory, now renamed the psychobiology laboratory. For seven decades, Richter would remain at Hopkins, a highly successful experimentalist whose early work did much to lend empirical substance to Meyer's programmatic calls to develop "psychobiology".

(C) Andrew Scull and Jay Schulkin 2009

*Andrew Scull, Department of Sociology, University of California, San Diego, 9500 Gilman Drive, La Jolla, CA 92093-0533, USA; e-mail: ascull@ucsd.edu Jay Schulkin, Departments of Physiology and Biophysics, Georgetown University, School of Medicine, Washington, DC 20057-1460, USA;

e-mail: jschulkin@acog.org
${ }^{1} \mathrm{~T}$ Lidz, 'Adolf Meyer and the development of American psychiatry', Am. J. Psychiatry, 1966, 123: 320-32.

${ }^{2}$ Cf. Michael Gelder, 'Adolf Meyer and his influence on British psychiatry', in G E Berrios and $\mathrm{H}$ Freeman (eds), 150 years of British psychiatry 1841-1991, London, Gaskell, 1991, pp. 419-35. 


\section{Andrew Scull and Jay Schulkin}

Like Greenacre, to whom he was married for ten years until an acrimonious divorce was finalized in 1930, Richter's career continued to flourish for decades after Meyer's forced retirement from his professorship in 1941, and like her, he emerged from Meyer's tutelage to become very much his own person. Still, in a variety of ways, the years the two younger figures spent as subordinates of Meyer exercised a decisive influence over their otherwise very disparate professional trajectories. And, amongst other things, we shall see that the complex relationships between the three of them have a great deal to teach us about a topic to which much scholarly attention has been devoted in recent years, the role of gender in scientific careers.

\section{Adolf Meyer in America}

Adolf Meyer was born in Niederweningen in Switzerland on 13 September 1866, the son of a Zwinglian minister. He trained as a neurologist under Auguste Forel at the University of Zurich. In the course of his studies, he spent a year abroad in Edinburgh, London, and Paris, where, among others, he worked under both John Hughlings Jackson and J-M Charcot. Concluding that his career opportunities would be better in the United States, he emigrated immediately after receiving his MD in 1892, initially settling in Chicago, one of the major centres of neurology in the United States. Despite his impressive European credentials, however, he was unable to find a full-time, salaried post at the new, Rockefeller-funded University of Chicago, and the following year, Meyer felt compelled to accept an appointment at the vast Illinois Eastern Hospital for the Insane at Kankakee, some ninety miles from the city.

It was not an auspicious beginning to his American career. Neurologists had been fiercely critical of institutional psychiatry in the preceding decade, criticism that would culminate in an excoriating address to the American Medico-Psychological Association in 1894 by the prominent Philadelphia neurologist Silas Weir Mitchell. Condemning psychiatrists for their scientific somnolence and ignorance, and for deliberately distancing themselves from the rest of the medical profession, Mitchell spoke scathingly of observing patients "who have lost even the memory of hope, sit in rows, too dull to know despair, watched by attendants: silent, grewsome [sic] machines which eat and sleep, sleep and eat". ${ }^{3}$

Mitchell could have been describing Meyer's own dispiriting encounter with the realities of institutional psychiatry. Indeed, just a few months later, Meyer wrote from Kankakee to G Alder Blumer, superintendent of New York State's Utica State Hospital, that he had become:

... more and more convinced that the atmosphere of the place shows little sign of being improved to such a degree as to make life satisfactory enough to spare energy for the work I am longing for. Catering towards political effects, towards more show and granting insufficient liberty of action, the administration discourages progress along sound principles. The library facilities are poor and the whole mechanism of medical work little promising although much better than when I came here. My courses on neurology and mental disease have certainly roused the interest of the

\footnotetext{
${ }^{3}$ Silas Weir Mitchell, 'Address Before the Fiftieth Annual Meeting of the American Medico-

Psychological Association', J. Nerv. Ment. Dis., 1894, 21: $443-73$.
} 
Staff, but the ground does not promise much fruit as long as the simplest means of clinical observation and examination are absent $!^{4}$

Meyer had begun his time at Kankakee by conducting large numbers of autopsies in an attempt to correlate brain lesions with psychiatric diagnoses. Soon, however, he realized that the disarray of the hospital's patient records and the absence of any systematic record of the patients' symptoms while they were alive, made all such endeavours pointless. ${ }^{5}$ Crucially, this led him toward a greater interest in studying the clinical course of psychiatric illness in living patients. ${ }^{6}$ If he were to train the hospital staff in systematic history taking and record keeping, he had perforce to develop the necessary techniques himself. Assembling the hospital staff and employing a stenographer to take notes as he examined patients, Meyer thus was led to pioneer a standardized case record. Soon, he was emphasizing the need to create a comprehensive record of all aspects of the patient's mental, physical, and developmental history, features that would become standard elements in Meyerian psychiatry, and the central feature of his future teaching and mentoring of young psychiatrists.

The year at Chicago and the two and a half years Meyer spent at Kankakee were decisive in bringing about his transition from neurology to psychiatry. Not only did they see the move from the morgue to the bedside and the development of a key instrument for recording the shape of psychiatric disorder (and for keeping psychiatrists busy), but these years also brought Meyer into close contact with the ideas of John Dewey, Charles Peirce and with American pragmatism, a set of philosophic doctrines that henceforth exercised a considerable hold on him and helped to fuel his enthusiasm for collecting endless amounts of data. A later move to Massachusetts led to intellectual ties to the third major figure among American pragmatists, the Harvard psychologist William James. As one of Meyer's most prominent later students commented, until he became aware of these biographical linkages, "I had long been puzzled-since I first met Adolf Meyer and recognized the similarity of his teachings to those of James and Dewey-how it happened that a Swiss had embraced pragmatism, indeed had found in it his natural voice."7

Kankakee also provided ready access to a broad array of clinical material, allowing Meyer to make some of his few original contributions to the neurological literature, while encouraging him to take a broader view of the problems of psychiatric illness. Meanwhile, the emphasis of the pragmatists on naturalism and on experimentalism as

\footnotetext{
${ }^{4}$ Meyer to Blumer, 23 Oct. 1894. Meyer Papers, Series I/355, Alan Mason Chesney Medical Archives of The Johns Hopkins Medical Institutions (hereafter CAJH.

${ }^{5}$ As Meyer himself recalled, "I found the medical staff ... hopelessly sunk into routine and perfectly satisfied with it ... A bewildering multiplicity of cases stared me in the face. It would have been the easiest thing for me to settle into the traditions-I had to make autopsies at random on cases without any decent clinical observation, and examinations of urine and sputum of patients whom I did not know, and for physicians who merely filed the reports ... whenever
}

I tried to collect my results, I saw no safe clinical and general medical foundation to put my findings on." Adolf Meyer, 'Aims and plans of the Pathological Institute for the New York State Hospitals', in Eunice E Winters (ed.), The collected papers of Adolf Meyer, 4 vols, Baltimore, Johns Hopkins University Press, 1950-52, vol. 2, p. 93.

${ }^{6}$ Eunice E Winters, 'Adolf Meyer's two and a half years at Kankakee', Bull. Hist. Med., 1966, 40: 441-58.

${ }^{7}$ Lidz, op. cit., note 1 above, p. 323; Ruth Leys, 'Meyer, Watson, and the dangers of behaviorism', J. Hist. Behav. Sci., 1984, 20: 128-49. 


\section{Andrew Scull and Jay Schulkin}

the key to exploring the universe, exercised a profound effect on Meyer. As he remarked many years later, "It was the work of American thinkers, especially of Charles S Peirce, of John Dewey and of William James, which justified in us a basic sense of pluralism, that is to say, a recognition that nature is not just one smooth continuity." " James would emphasize that "pragmatism is uncomfortable away from facts", 9 and Meyer emphasized "the facts" like a mantra. His central conception of psychobiology can likewise be seen as echoing the pragmatists' emphasis on biological adaptation, the processes of problemsolving, and whole-body activity.

Besides the overcrowding, isolation, and lack of resources that were endemic features of most state hospitals in this period, the Illinois asylums were notoriously at the mercy of state politicians, who viewed them as patronage plums. Two years after Meyer had taken up his post, S V Clevenger, the superintendent at Kankakee, found himself under growing political pressure. He succumbed in a matter of months. Some observers concluded that his erratic behaviour and "delirious delusions" were the product of his alcoholism. Meyer simply noted that he "broke down" under pressure, "so that he was considered insane even by his friends". Meyer must by now have begun to question his decision to leave Switzerland for the allegedly greener pastures of North America, and it was surely with great relief that in 1895 he received an offer to move to Worcester State Hospital in Massachusetts, as director of research.

Henceforth, Meyer's own career moved from strength to strength. Six years at Worcester led to an appointment as director of the Pathological Institute of the New York State Hospitals, and shortly thereafter, a courtesy position as professor of clinical medicine at Cornell University Medical College. Then, in 1908, came the call to Johns Hopkins, where he occupied the first chair in psychiatry, and headed the newly established and generously endowed Phipps Clinic.

At Worcester, modelling his approach on the best German clinics and mental hospitals, Meyer developed links to the local Clark University and developed a programme to bring in four or five new assistants a year, recruited from the best mental hospitals in the country on the basis of their academic records and a competitive examination. Little or no formal instruction in psychiatry was provided at American medical schools in this period, a reflection of the specialty's marginality and low professional status. Meyer's new men (actually the twenty-nine appointments he made included two women) were to be the shock troops of a new scientific psychiatry, employing serious and sustained clinical and pathological research to uncover the roots of mental disorder. With their aid, Meyer began to develop the eclectic approach he would soon dub "psychobiology", and in many instances, his young assistants went on to become the leaders of the next generation of American psychiatrists. Three of them, indeed, subsequently served as presidents of the American Psychiatric Association. ${ }^{10}$

\footnotetext{
${ }^{8}$ Winters (ed.), op. cit., note 5 above, vol. 2 , p. 28; see also Ruth Leys and Rand B Evans (eds), Defining American psychology: the correspondence between Adolf Meyer and Edward Bradford Titchner, Baltimore, Johns Hopkins University Press, 1990.
}

\footnotetext{
${ }^{9}$ William James, Pragmatism, New York, Meridian, 1958. (Original edition 1907.)

${ }^{10}$ Gerald Grob, The state and the mentally ill: a history of the Worcester State Hospital in Massachusetts, 1830-1920, Chapel Hill, University of North Carolina Press, 1966, pp. 287, 297-98.
} 


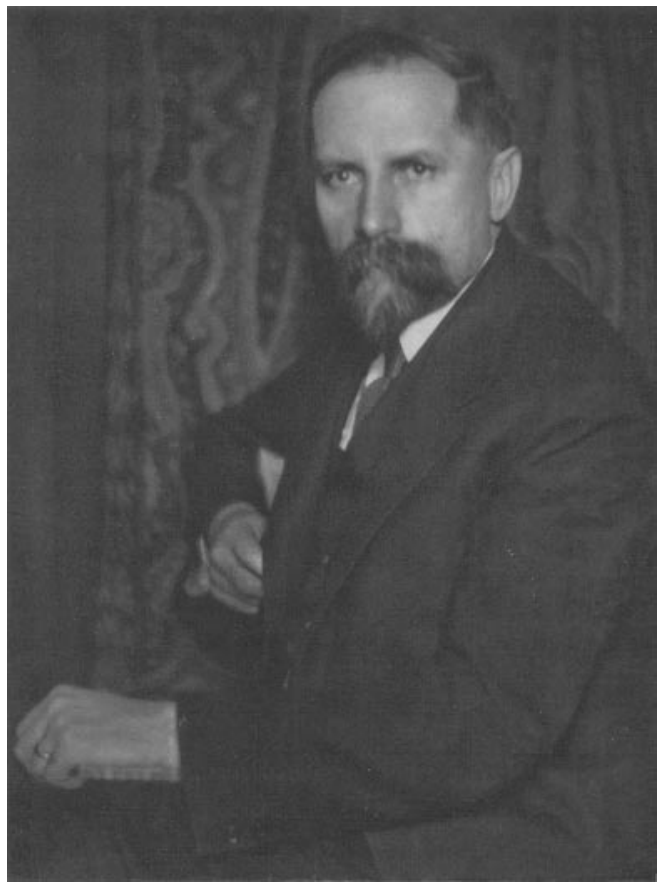

Figure 1: Adolf Meyer. (Reproduced by courtesy of the Alan Mason Chesney Medical Archives, Johns Hopkins Medical Institutions.)

The move to New York was yet another step up the professional ladder. The New York State mental hospital system was by far the largest in the country, and its Pathological Institute, intended as a centre of psychiatric research and training, was potentially a very influential bureaucratic niche. However, under its founding director, Ira Van Gieson, the Institute had achieved little. A pathologist by training, Van Gieson was contemptuous of institutional psychiatry, viewing its practitioners as poorly trained and "ignorant" of medical science. ${ }^{11}$ But the programme of basic research he had sought to establish had little obvious therapeutic or intellectual payoff in its first half dozen years, leaving him politically vulnerable to the machinations of the superintendents and their political supporters, and by the autumn of 1901, he found himself out of a job. ${ }^{12}$

Meyer had been consulted privately about the deficiencies of the Institute under Van Giesen, and after some hesitation, he now agreed to take on the task of giving it a new direction. So far from being contemptuous of clinical psychiatry, Meyer embraced it, and this at once made for better relations with the superintendents. His work at Worcester had already begun to win him a national reputation, and he now set about

\footnotetext{
${ }^{11}$ For Van Gieson's vision of the Pathological Institute's future, see his 'Remarks on the scope and organization of the Pathological Institute of the New York State Hospitals', State Hospitals Bulletin, 1896, 1: $255-74 ; 407-88$.
} 


\section{Andrew Scull and Jay Schulkin}

remaking the Institute. He established an outpatient clinic, standardized record-keeping and statistics state-wide, and sought to provide research training for mental hospital staff throughout the system. His co-operative stance towards the hospitals, his expressed desire to "raise the standards of medical work in the State institutions", and his frequent visits to the various mental hospitals throughout the state helped to smooth ruffled feathers. But they did not, in the end, provoke a reciprocal engagement on the part of the heads of most institutions. And making matters worse, Meyer's insatiable appetite for collecting "facts" was not matched by any comparable creativity in organizing or making sense of this mass of material. ${ }^{13}$

None the less, Meyer's intimidating Teutonic manner, the prestige of the institutions and individuals at which and under whom he had trained, his neurological background, and his extensive knowledge of the European and particularly of the German literature on psychiatry all served to bolster his standing. Thus, the decision to appoint him as the first professor of psychiatry at Hopkins was in some senses predictable. Not completely, however, for William Henry Welch, the dean of the medical school, had first approached Stewart "Felix" Paton, an immensely wealthy Princeton man who had studied in Europe and written one of the most widely used psychiatric texts of the time, and who possessed more stellar social connections than Meyer. But Paton had no interest in being tied down by a full-time clinical appointment, and urged Welch to appoint Meyer instead.

Hopkins had opened its doors in 1893, and was the first American medical school to adopt the German model of combining medical education and research. By almost any measure, it was America's premier medical school in these years. Apart from its institutional innovations, the stature of its first four chairs-Welch, William Olser, William Halsted and Howard Kelly — had done much to cement its dominance. In an era when most medical schools ignored psychiatry, Meyer's arrival in Baltimore represented a coup for the specialty, as well as for him personally.

His chair at Hopkins provided Meyer with an extraordinarily powerful and prominent base on which to build his influence in the discipline, and he used it to great effect. The 1920s and 1930s saw the expansion of academic psychiatry across the United States, with much of the growth underwritten by the munificence of the Rockefeller Foundation, which had decided by the late 1920s to make the specialty its top priority in the field of medicine. The stream of students passing through Hopkins in these decades went on to prominent positions in these new departments, bearing with them the influence of Meyer's eclecticism, and declaring their allegiance to Meyerian psychobiology. By one estimate, in 1937, as many as 10 per cent of all academic psychiatrists in the United States had trained at Hopkins under him. ${ }^{14}$ His influence extended abroad, particularly to Britain, where Aubrey Lewis in London and David Henderson in Edinburgh came to dominate the discipline, both having received extensive training at Hopkins under Meyer. ${ }^{15}$ And his dominance was all the greater since so many of his pupils remained

\footnotetext{
${ }^{13}$ See the useful discussions in ibid., pp. 128-31; and Ruth Leys, 'Adolf Meyer: a biographical note', in Leys and Evans (eds), op. cit., note 8 above, pp. 43-6.

${ }^{14}$ Frank G Ebaugh, 'Adolf Meyer's contribution to psychiatric education', Bulletin of the Johns
} 
in his shadow. Smith Ely Jelliffe once commented waspishly that Meyer had put "partly castrated pupils in professional chairs" all across the country. ${ }^{16}$

Elected president of the American Psychiatric Association in 1928, Meyer also played a leading role in the establishment of the American Board of Psychiatry and Neurology in 1934, chairing its organizational meeting and serving on the committee that administered its first qualifying examination. Though he grew increasingly hostile toward Freud and psychoanalysis ${ }^{17}$ - a stance that helps explain his rapid eclipse following his retirement in 1941, for psychoanalysis was then about to cement its quarter-century long dominance of American psychiatry - in the years before the outbreak of the Second World War, his influence was all-pervasive. Yet it was a professional dominance that rested more on the prestige of his European training, the power that flowed from his Hopkins position, and the number of academic psychiatrists who owed their careers to his sponsorship, than on his intellectual contributions to the understanding and treatment of mental illness.

Meyer's original contributions to neurology and neuroanatomy virtually ceased once he arrived in Baltimore. ${ }^{18}$ His psychiatric papers from his three decades at Hopkins were programmatic rather than substantive, and they were written in a notoriously dense and impenetrable prose. But faced by the bewildering complexities of an array of disorders whose aetiology and treatment remained largely a matter of guesswork and improvisation, Meyer's notion of psychobiology provided an elastic overarching framework within which a whole array of hypotheses and interventions could be accommodated; and his stress on the meticulous collection of detailed case histories created a host of tasks with which his students could busy themselves.

\section{Building Careers at Johns Hopkins}

Among those attracted to work under Meyer in his first decade at Hopkins were two young scientists with whom he would develop unusually close personal ties. The first of these, Phyllis Greenacre, was a talented and determined woman from Chicago, who had overcome paternal disapproval (and her father's refusal to pay for her medical education) to secure both a BS and an MD from the University of Chicago. Her ambition led her to write to Meyer in 1916 asking for a position on his staff, and her intellectual talents (enthusiastically endorsed by Dean Dodson of the Chicago Rush Medical School), secured her the post. Two years later, Curt Richter, a Harvard graduate with a far more

Berrios and Freeman (eds), op. cit., note 2 above, pp. 419-35.

${ }^{16}$ Smith Ely Jelliffe to Harry Stack Sullivan, 1 June 1937, Jelliffe Papers, Library of Congress, Washington, D.C.

${ }^{17}$ For discussions of Meyer's complicated relationship with Freud and psychoanalysis, see Ruth Leys, 'Meyer's dealings with Jones: a chapter in the history of the American response to psychoanalysis', J. Hist. Behav. Sci., 1981, 17: 445-65; and Nathan G Hale, Jr, The rise and crisis of psychoanalysis in the United States: Freud and the Americans, 1917-1985,
New York and Oxford, Oxford University Press, 1995, esp. pp. 168-72.

${ }^{18}$ Thomas Turner, for example, in a generally hagiographic account of the Hopkins faculty in these years, judges that "Meyer seems to have done very little research in the accepted sense after coming to Hopkins" and pronounces himself unable to discern "any direct contribution to knowledge in the field"-a damning assessment of a Hopkins professor. See Thomas B Turner, Heritage of excellence: the Johns Hopkins medical institutions, 1914-1947, Baltimore, Johns Hopkins University Press, 1974, pp. 441-4. 


\section{Andrew Scull and Jay Schulkin}

mixed academic record arrived on the scene, initially to work with John B Watson, the increasingly prominent behavioural psychologist.

Watson had recently moved his laboratory from the Psychology Department to Meyer's Phipps Clinic, so Richter found himself on the periphery of Meyer's academic empire. He had been attracted to Baltimore and to Watson by an interest in animal physiology, ${ }^{19}$ and he quickly began work on the behaviour of the ubiquitous laboratory rat. (By an odd coincidence, it was Meyer who had introduced the rat as an experimental subject to the American university. $)^{20}$ Largely left to his own devices, and early on inclined to search for internally generated behavioural control mechanisms, rather than the external influences on behaviour that fascinated Watson, Richter none the less quickly absorbed his mentor's emphasis on precise measurement and rigorous experimentation as the route to scientific legitimacy. Within three years, Richter had completed a $\mathrm{PhD}$ thesis on 'The behavior of the rat: a study of general and specific activities' (1921). By then, though, embroiled in a sex scandal that wrecked his first marriage, Watson had been forced to resign his Hopkins' professorship, his unwilling departure fuelled in part by some behind the scenes manoeuvring by Meyer, with whom his relations had become increasingly acrimonious over the years.

Besides his fierce intellectual disagreements with Watson, ${ }^{21}$ Meyer seems to have been motivated by his own sexual prudery, ${ }^{22}$ and by concerns about the potential damage Watson's sexual dalliance threatened to impose on the university. He had engaged in an extensive private correspondence with Watson when rumours of the affair reached him from the psychologist Stanley Hall. In the course of what Watson must have thought was a private exchange of letters, he had revealed (foolishly as it would turn out) the depth of his unhappiness with his marriage and the crucial details of his affair. ${ }^{23}$ In what many would regard as a serious violation of trust, Meyer subsequently passed this correspondence on to the Hopkins President, Frank Goodnow, and privately advised him that Watson must go: "Without clean cut and outspoken principles on these matters we could not run a coeducational institution, nor would we deserve a position of honor and respect before any kind of public, nor even before ourselves." 24 Six days later, under severe pressure from the university, Watson submitted his resignation. Disingenuously, when the New York cardiologist Robert Levy wrote to him about the matter eighteen months later, Meyer responded that "Personally, I did all in my power to smooth over

\footnotetext{
${ }^{19}$ Decades later, Richter reported that Robert Yerkes (who had given him the only " $A$ " grade he earned at Harvard), had urged him to read Watson's book on Animal education, an intellectual encounter that prompted him to move to Hopkins. See C Richter, 'It's a long way to Tipperary, the land of my genes', in Donald A Dewsbury (ed.), Leaders in the study of animal behavior: autobiographical perspectives, Lewisburg, PA, Bucknell University Press, 1985, p. 369.

${ }^{20} \mathrm{C}$ A Logan, 'The altered rationale for the choice of a standard animal in experimental psychology. Henry H Donaldson, Adolf Meyer and the albino rat', Hist. Psychol., 1999, 2: 3-24.

${ }^{21}$ On these differences, see Leys, op. cit., note 7 above.
}

\footnotetext{
${ }^{22}$ This was a feature of Meyer's character that Phyllis Greenacre attributed in part to his Zwinglian upbringing. Interview with Andrew Scull, New York City, 22 Dec. 1983. It is also discussed in passing in Ruth Leys, op. cit., note 17 above, p. 456, which includes a claim that "sexuality was an area of personal tension for Meyer during these years".

${ }^{23}$ Watson to Meyer, 13 Aug. 1920; Meyer to Watson, 17 Aug. 1920; Watson to Meyer, 18 Aug. 1920, and assorted notes, Meyer Papers, Series I/3974/20, CAJH.

${ }^{24}$ Meyer to Goodnow, 29 Sept. 1920, Johns Hopkins University Archives, Series III/11.
} 
the catastrophe, but there was nothing to be done in view of the fact that the authorities had evidently made up their minds to deal drastically with the matter." 25 One is tempted to conclude that a previous personal betrayal was here compounded by a lie. ${ }^{26}$

In Watson's place as the head of the psychological laboratory, Meyer promptly appointed the young and inexperienced Richter, a move that, over time, would pay large dividends to both men. ${ }^{27}$ As well, he invited Richter to attend his staff rounds and to give some lectures, drawing the young man away from Watson and into his own intimate circle.

Meanwhile, Phyllis Greenacre's first years at Hopkins had proved unexpectedly difficult. Her psychiatric training at Chicago Rush had been minimal, and the stress this created for her may have been one factor that led to a deep and for a time disabling depression, one that eventually required temporary hospitalization. Meyer none the less kept her on staff, and during this period developed a distinctly paternalistic interest in her future, one that amounted, as he himself confessed in a letter to her, almost to his assuming the role of a father figure, substituting for the estranged parent with whom Greenacre had little or no continuing contact. "Above all things," Meyer had urged her, "do not forget that hard as it may have been in the past to get help and a chance for free discussion with yr [sic] own family, you can count on an absolutely frank and thoughtful and yet not meddlesome hearing and discussion with your more neutral but none the less keenly interested 'chief' who has always felt himself to be, as far as this can be accepted, in loco parentis (and I hope without suggesting paternalism)."28

Greenacre had returned to work in the spring of 1918, and so when Richter was drawn into Meyer's orbit, it was inevitable that the two young scientists would become acquainted. Within a matter of months, they had developed a romantic relationship, and Greenacre was approaching her surrogate father for advice, just as he had urged her to do. Junior Hopkins staff in this era required the permission of the university's trustees before they could marry, and there were, besides, few precedents for married female staff members attempting to continue their professional careers. ${ }^{29}$ Her "chief's" approval was thus of great importance to her on both a personal and a professional level.

\footnotetext{
${ }^{25}$ Meyer to Levy, 6 March, 1922, Meyer Papers, Series I/2341/1, CAJH.

${ }^{26}$ A more benign interpretation of Meyer's actions in the case is offered in Ruth Leys' paper on 'Meyer's dealings with Jones', pp. 455-6 (see note 17 above), where Meyer is described as having "sympathized" with Watson (though deploring his sexual misbehaviour), and it is claimed that he "hated to lose [him]". The misrepresentations to Levy are explained away as an indication of Meyer's "ambivalence". This interpretation strikes us as strained, given Meyer's proactive role in securing Watson's dismissal, and the long-standing intellectual disagreements between the two men. We note, too, that Leys' discussion of Meyer's behaviour in the censoring of a paper by Jones on Freud's psychology and blocking a possible appointment for Jones at Hopkins reveals a similar pattern of double-dealing and deceit.
}

\footnotetext{
${ }^{27}$ Richter's appointment involved passing over an application from the far more senior and prominent Robert Yerkes, who had taught him at Harvard. See Kerry W Buckley, Mechanical man: John Broadus Watson and the beginnings of behaviorism, New York, Guilford Press, 1989; Meyer to Watson, 12 April 1921, Meyer Papers, CAJH Series I/3974/21. Perhaps Meyer thought he could more readily dominate the younger man. Significantly, Richter's appointment led to the Psychological Laboratory being renamed the Psychobiological Laboratory. For further elaboration of this point, see Jay Schulkin, Curt Richter: a life in the laboratory, Baltimore, Johns Hopkins University Press, 2005, pp. 16-19.

${ }^{28}$ Meyer to Greenacre, undated (probably late summer 1919), Meyer Papers, CAJH Series XV.

${ }^{29} \mathrm{On}$ the Hopkins policy prohibiting marriages between junior members of staff on pain of forced resignation, see Turner, op. cit., note 18 above,
} 


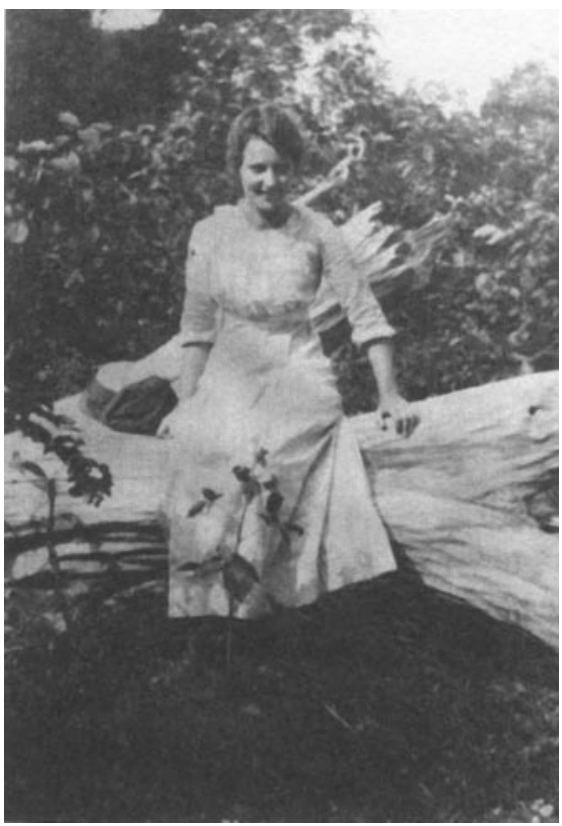

Figure 2: Phyllis Greenacre as a young woman. (Photograph kindly supplied by Dr Peter Richter.)

Initially, however, it was not forthcoming. Instead, Meyer openly worried that her desire to marry might reflect the emotional turmoil she had gone through the year before. Greenacre hastened to assure him that this was not the case: "I have never looked upon marriage as an attempt at a therapeutic adjustment as promising of any success or stability. It has always seemed to me that the half-digested problems are bound to be augmented by the new complexities." As she hoped Meyer had observed, "I have been more at ease this past year ... Certainly less energy has gone into the vague states of tense depression which used to swamp me; and my thinking has, I believe, become more purposeful, with less of the depressive musing." 30

But Meyer had misgivings that extended beyond a concern about Greenacre's emotional state. There were more practical objections to a marriage. Both Greenacre and Richter were in the early stages of building professional careers, an extremely demanding process from which marriage (and children) could prove a very significant distraction: "I have seen a few happy student marriages, but also [know] how important it is to be free during the hard period during which one is tested out by the hard world for one's final career."

Her own career, he noted with evident satisfaction, was developing well, but Richter's had scarcely begun and seemed far less defined and secure. The uncertainties worried him. Richter's European training in engineering, his catholic intellectual tastes (which

pp. 237-8. Officially, the policy was still in place at the outbreak of the Second World War.
${ }^{30}$ Greenacre to Meyer, 14 Aug. 1919, Meyer Papers, CAJH Series XV. 
extended at this point in his career to an interest in psychoanalysis), his cleverness in the laboratory, and his biological bent, all made for intriguing possibilities. But his intellectual agenda was still confused and inchoate. "He is a man whose potentialities I find it difficult to evaluate ... [someone who has] a certain difficulty in getting focused. I have had the feeling that whenever I thought Richter had focused on a point he was off on a tangent without having finished the starting point." Before doing anything irrevocable, he urged his protégée to try to weigh things rationally and carefully: "If the practical balance proves promising, there is no reason why your two careers could not blend to a reasonable extent. And the question in my mind is whether this balance cannot be gaged $[s i c]$ within a reasonable time and that without interfering with the frankness and sincerity of your relationship, but also without engaging first in the life-contract of marriage before the balance of facts is reasonably clear."

Seeking further arguments to dissuade her, Meyer spoke approvingly of how much Greenacre's work mattered to her. Marriage might jeopardize her career prospects, and how would she feel then? "I remember well your sensitiveness and reaction to the appearance of a slight in promotion a year ago when I had planned to lead you towards the laboratory and Dr. Fairbank [another young female associate] took a line for work for which she seemed better fitted, not than you, but better than for the other type of work." Phyllis had made her unhappiness vividly clear. She should understand that "that type of preferences and deferments will be very [much] larger with a married couple, and I should feel it very wrong that you should be exposed to all of that instead of having a chance to become the vigorous and capable person you give every promise to become if at least you are not swamped by incidental difficulties and especially difficulties accruing to Mr. Richter." 31

Meyer's prudential arguments, powerful as they may have been, failed to achieve their objective. Ignoring his strictures about the possible "complications which go with premature marriages", she seized on a passage in one of his letters that promised "whatever you may decide I shall try to be helpful". ${ }^{32}$ She and Richter, she informed him, would marry on 1 September before the academic year got under way. ${ }^{33}$ A clearly unhappy Meyer again urged caution, but signalled that "if the course of things must be so ... I accept the situation".

Perhaps disconcerted by her mentor's reaction, or perhaps because of a change of heart, Greenacre soon wrote to announce that "the plans of which I first wrote you have been entirely disrupted". ${ }^{34}$ But the disruption proved only temporary. Meyer continued to counsel her not to proceed: "It is not your mutual affections, but the complications that go with premature marriage that I fear might be apt to create perplexities which may hinder the one or the other or both [of you], and especially also Mr. Richter and possibly in ways in which you may have to suffer without being able to help. ${ }^{35}$ But he found

\footnotetext{
${ }^{31}$ Meyer to Greenacre, 1 and 24 July 1919, CAJH Series XV.

${ }^{32}$ Meyer to Greenacre, n.d., [1919]. Meyer Papers, CAJH Series XV.

${ }^{33}$ Greenacre to Meyer, 14 August 1919, Meyer Papers, CAJH Series XV.
} 


\section{Andrew Scull and Jay Schulkin}

himself ignored. In the spring of 1920, the two young scientists married, and within weeks Greenacre was pregnant.

Women pursuing careers in academic medicine were rare in the early twentieth century. Married women were even scarcer. Married women with a child or children were the rarest creatures of all. The expectation on all sides was that such women would gracefully retire from the fray, perhaps initially intending the break to be only temporary, though in reality the interruption generally proved fatal to any serious ambitions as a scientist. Marriage and a family were a normal part of most men's career trajectories. It was quite otherwise for women.

A few years earlier, for example, Dorothy Reed had been one of the most promising young medical scientists at Hopkins. After taking the necessary science courses at MIT in 1895-96, she entered the Hopkins medical school, where she finished fifth in her graduating class. Next she obtained posts under two of the leading figures at the school, serving as an intern under William Osler in 1900, and then obtaining a fellowship in pathology with William Welch the following year. Two years later she moved to take up a residency in paediatrics at Babies Hospital in New York.

During her time in the Hopkins laboratories, Reed definitively differentiated tuberculosis from Hodgkin's disease, and discovered the blood cell disorder characteristic of the latter, the cells in question being eponymously dubbed "Reed cells". International recognition followed the publication of her results in 1902, and all seemed set for a major career in medicine - until her marriage in 1906 to a professor of physics at the University of Wisconsin, Charles Elwood Mendenhall. Immediately thereafter, in rapid succession she had four children (the first of whom died at one day old, and the second before he was two), and for eight years she stayed at home to care for the survivors. Her once glittering professional prospects all but vanished. When she returned to medicine it was in the marginal and stigmatized field of public health-not, her male contemporaries sniffed, a serious branch of medicine.

Those who opposed allowing females into medicine saw her as a prime example of why it was foolish to "waste" precious medical space on the weaker sex. When Harvard debated the question of whether to open its medical school to women, Alice Hamilton informed her that the opponents of such a move specifically cited her case. Here, they proclaimed, "was an able woman who had married and failed to use her expensive medical education". ${ }^{36}$ That it might be possible to balance a career in academic medicine with marriage and motherhood struck most contemporary observers as verging on the delusional, and Reed's career path proved it.

Greenacre, however, was determined to prove the conventional wisdom wrong. Her daughter Ann was born in February 1921, but even a second pregnancy, and the birth of her son Peter in May 1922, did not shake her resolve. Not that Hopkins had made any attempt to ease her difficulties: for the first birth, as she explained to Meyer, "the hospital was unwilling to grant me any extra time [off]" and she had had to use her vacation allowance instead. In January 1922, she asked her mentor to try to secure her an extra "month or six weeks of vacation this summer. I shall have my second baby in

\footnotetext{
${ }^{36}$ Quoted in Regina Morantz-Sanchez, 'Dorothy Reed Mendenhall', in John A Garraty and Mark C
}

Carnes (eds), American national biography, New York, Oxford University Press, Online Edition, 2000. 
May which will of necessity absorb three weeks of the usual allotment of four weeks." It is clear, however, that she did not expect the appeal for more time to spend with her infant son to succeed, and she announced in advance that she would not let that deter her: "If that is not possible next summer either, I shall accept the time in May as a good enough investment and let it go at that." ${ }^{37}$ Hiring a black nanny to care for the children in her absence, Greenacre just got on with her work.

But her work stagnated. In her early years at Hopkins, Greenacre had done extensive research on the pathophysiology of syphilis. Tertiary syphilis was responsible for between 10 and 20 per cent of male mental hospital admissions in these years, and the work on the pathology of the central nervous system allowed Greenacre to draw more directly upon her prior training in Chicago. Each time she sought to bring her research to closure, however, Meyer raised difficulties. The papers she wrote never seemed to satisfy him. Whenever she showed him a draft, he would raise a new objection, or suggest a further extension of her research. In the event, the work never appeared in print, damaging her efforts to begin to make a name for herself through publication. ${ }^{38}$

Nor was that the only difficulty she faced. Meyer had assured her during their exchange of letters about her impending marriage that "I am much less prejudiced than most organizers against favoring women and married couples". ${ }^{39}$ Less, perhaps, especially if the women remained single: Meyer had hired Ruth Fairbank and Esther Richards to work alongside Greenacre, and Richards served as Meyer's principal clinical associate and director of the outpatient service at the Phipps Clinic from 1920 until her retirement in 1951. But, as Phyllis found once she was married, "less prejudiced" still left much room for unequal treatment. Despite her obvious talents, and her personal closeness to Meyer, Greenacre found her opportunities for professional advancement were sharply curtailed. Her salary remained static, and while the other women were given the opportunity to expand their professional horizons, she remained stuck with the same rank and title, a source of growing embarrassment as well as frustration.

What made matters still worse was that she saw Richards and Fairbank as "second rate people" advancing "at the expense of first rate people" (among whom she clearly numbered herself). Esther Richards, in particular, was "much disliked, very cold, often cruel in front of patients, much disliked by the staff", someone afflicted with "scoliosis, a kind of hunchback", with a personality to match. To watch Meyer "lean over backwards" to help such people while she was left to struggle was immensely galling. ${ }^{40}$

\footnotetext{
${ }^{37}$ Greenacre to Meyer, 5 Jan. 1922, Meyer Papers, CAJH Series XV.

${ }^{38}$ Phyllis Greenacre, interview with Andrew Scull, New York City, 22 Dec. 1983. Sixty years and more after these events, Meyer's obstructionism still produced a visible emotional reaction in Greenacre. She had earlier given to Ruth Leys a fuller account of Meyer's repeated interventions to block its publication. These actions continued into the late 1930s, despite his description of it in a meeting of his staff "as the best piece of work to come out of the clinic". Further fuelling Greenacre's sense of
}

grievance, having said that, Meyer promptly attributed the paper to Ruth Fairbank. Ruth Leys, interview with Phyllis Greenacre, New York, 16 June 1982. (We are grateful to Dr Leys for permission to quote from her notes on this interview.)

${ }^{39}$ Meyer to Greenacre, no date [July 1919], Meyer Papers, CAJH Series XV.

${ }^{40}$ Phyllis Greenacre, interview with Ruth Leys, New York City, 16 June 1982, from which these quotations are taken. Greenacre's memories were equally bitter when she spoke of these matters with one of us in December 1983. 


\section{Andrew Scull and Jay Schulkin}

Constantly pressed for funds, Greenacre took on other work on the side as and when she could in a frantic effort to make ends meet, including a sex survey for the American Social Hygiene Association. It made for a punishing schedule. There was a three month rotation in a Maryland state hospital, a dismal and daunting experience dealing with hopeless, chronic patients on badly overcrowded wards. Back at the Phipps, she supervised Meyer's laboratory for him, and sought to find ways for "developing further work with students to include the relation of the laboratory examinations to the clinical material". Then there was the supervision of "the rotation of internes [sic] in the laboratory". As for original research of her own, "follow-up work [with patients at the Phipps Clinic] is now absorbing all of the spare time I can manage during the day; usually 2 or 3 nights a week in interviews with patients who cannot come during the day; and 2 or 3 evenings a week spent in abstracting old histories at home. The unavoidable evening interviews [with patients] could be simplified if I were able to establish an office [nearby] ... rather than making the extra night trips to the clinic. This, however, is quite out of the question on my present income which is limited strictly to the clinic salary." 41

Meanwhile, the equally ambitious Curt Richter had thrown himself enthusiastically into an ever more elaborate research programme of his own, working long hours in the laboratory on his animal experiments. Richter was proving to be something of a virtuoso at designing and constructing new pieces of equipment that allowed him to conduct his research, his hands-on skills allowing him to develop new ways of studying animal physiology and behaviour. Working with rats, he developed numerous techniques to monitor their behaviour, constructing an "activity cage" filled with instruments that enabled him to observe and record patterns of activity and inactivity, sleep and wakefulness, and to manipulate such things as light, temperature, and the availability of food and water.

On another front, Richter continued work on the neurological basis of human behaviour, a topic he had been introduced to by Watson. Studying the grasp reflex, he conducted some experiments using human infants as subjects. His wife initially assisted him with these studies in the laboratory, and they may have used their own children as experimental subjects.

Much of Richter's manual skill and dexterity, and his cleverness at inventing new instruments, derived from his childhood experiences. His parents had immigrated from Germany and set up an iron factory in Denver, a business his mother continued to run when his father was killed in a hunting accident while Richter was still a young boy. Hanging round the factory, assembling and disassembling clocks and other bits of machinery, Curt had honed his skills as an engineer and inventor.

Deeply committed to measurement and data, Richter quickly began to expand the work in his laboratory that sought to link biology and behaviour, in the process giving substance to Meyer's programmatic commitment to psychobiology, particularly through an emphasis on self-regulation and behavioural adaptation to the environment. He had adopted as his own Meyer's emphasis on the total organism, and found Meyer's pragmatism equally congenial. Meyer visited the laboratory regularly, and the two men grew

\footnotetext{
${ }^{41}$ Greenacre to Meyer, 5 Jan. 1922, Meyer

Papers, CAJH Series XV.
} 

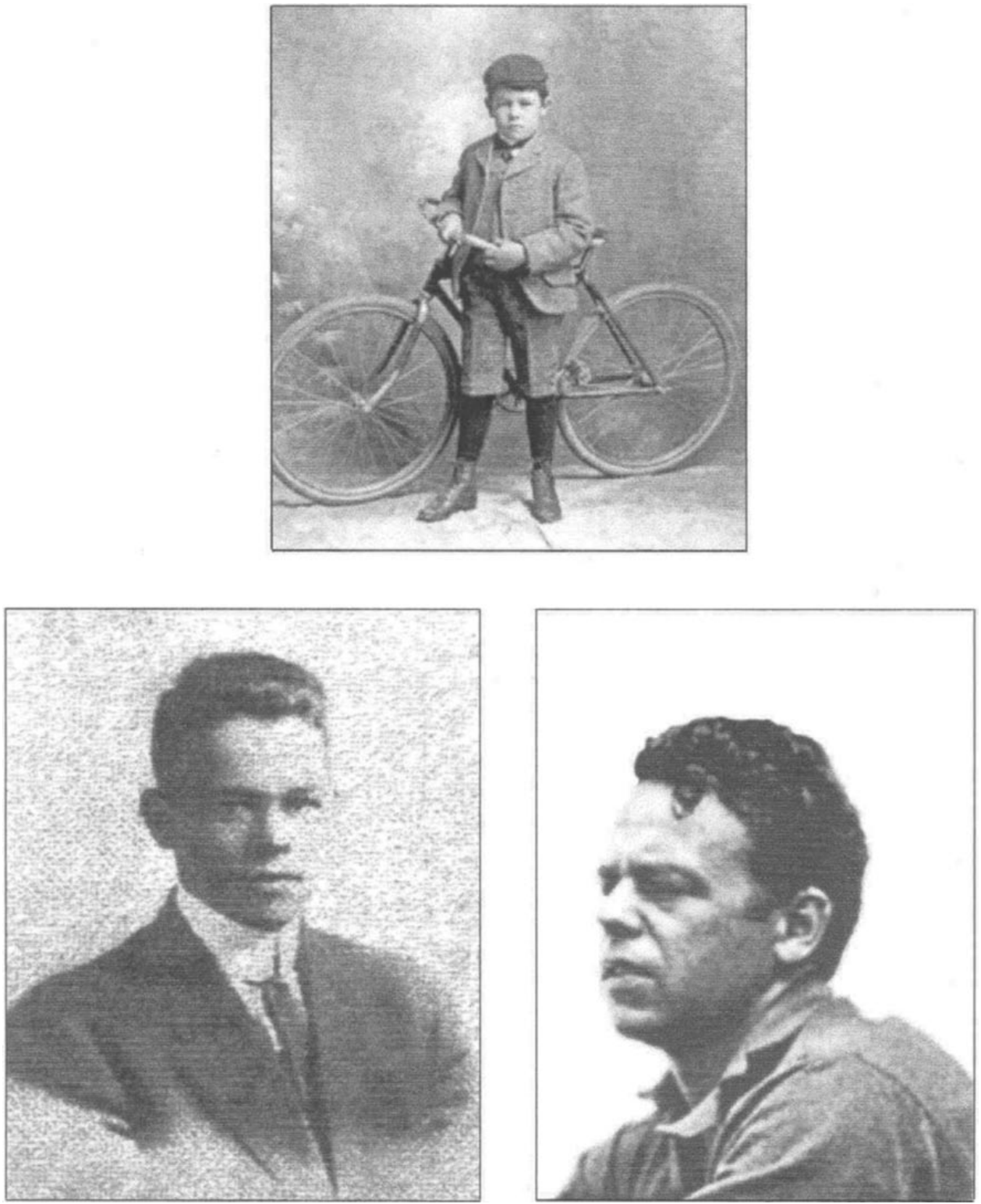

Figure 3: Curt Richter as a young boy (1905), young man (1912), and young scientist. (Reproduced by courtesy of the Alan Mason Chesney Medical Archives, Johns Hopkins Medical Institutions.) 


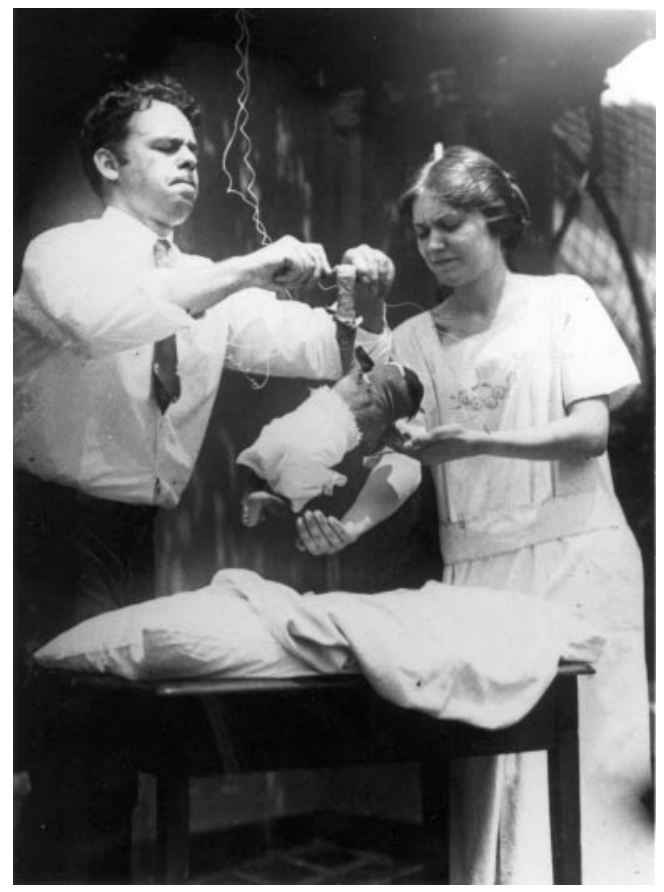

Figure 4: Curt Richter and Phyllis Greenacre conducting an experimental study of the grasp reflex in human infants. (Reproduced by courtesy of the Alan Mason Chesney Medical Archives, Johns Hopkins Medical Institutions.)

close. Just as Greenacre's estrangement from her parents had made Meyer something of a substitute parent, so too for the fatherless Richter, Meyer became a father figure, someone whose advice and counsel he regularly sought, and on whom he depended for both material and emotional support. Meyer was generally viewed as an autocratic and intimidating figure, but the young couple enjoyed significant marks of his favour, including regular invitations to his home to dine with him and Mrs Meyer. ${ }^{42}$

Interacting regularly with other Hopkins scientists outside Meyer's domain, Richter's experimental virtuosity and the meticulous care with which he conducted his investigations drew their admiration. Baffled as they might be by Professor Meyer's abstruse philosophical statements, here was work of substance, whose worth they quickly recognized. Psychology, in Richter's hands, did seem to them to be developing into the science the infant discipline insistently proclaimed itself to be. During the decade of the 1920s, then, Richter's work was of growing importance scientifically, and also

\footnotetext{
${ }^{42}$ Richter's personal closeness to Meyer is evident in his autobiographical talk about his years at Hopkins, given to medical residents in 1973-74. See 'Reminiscences', unpublished paper, Richter Papers, CAJH Series 1, Mss: Adolf Meyer. The frequent
}

weekend trips to dine with the Meyers were confirmed by his son, Peter Richter, in an interview with Andrew Scull, Garrison, New York, 15 Aug. 1996. 


\section{The Careers of Adolf Meyer, Phyllis Greenacre, and Curt Richter}

played a very substantial role in legitimizing Meyer's whole enterprise. ${ }^{43}$ His first series of publications, appearing between 1921 and 1925, adumbrates themes that would resonate through all his later work, extending even into the 1980s: the determinants of spontaneous activity; the importance of biological clocks; endocrine control of behaviour; the origin of the electrical resistance of the skin; brain control of the motor system; and a device to aid in the measurement of salivation. ${ }^{44}$ Particularly striking was his discovery of circadian biological rhythms, an instance where his childhood fascination with clocks led indirectly to a quite profound set of insights into the role of internal clocks in animal and human activity and inactivity.

For all Phyllis Greenacre's frustrations, to most outside observers during the early 1920s, she and Curt Richter seemed to be a remarkable couple, both launched on careers of exceptional scientific promise. Only Greenacre, among the handful of women on the Hopkins staff, had managed to combine work, marriage, and motherhood, and her determination to succeed professionally seemed undaunted by the obstacles she faced. In reality, however, Meyer's worries about the stresses the two of them would face were proving prescient, though his own actions were helping to make his prophecy a selffulfilling one.

The severe financial constraints the two young academics faced were exacerbated as their children grew beyond infancy. Adding to the strains on their relationship, their workaholic schedules gave them little time together. The marriage began to fall apart, and, as part of a vicious cycle, Greenacre experienced new episodes of depression and began to overeat. She gained some forty or fifty pounds in the months after the birth of her son Peter, which led to a dramatic change in her appearance, though no one around her seemed to grasp the significance of this development. Divorce seemed out of the question. Its stigma remained great, and, in any event, it would have compounded their financial problems. The path of least resistance was to immerse themselves more

\footnotetext{
${ }^{43}$ See, for example, the discussion in A McGehee Harvey, Adventures in medical research: a century of discovery at Johns Hopkins, Baltimore, Johns Hopkins University Press, 1976.

${ }^{44}$ See Paul Rozin, 'The compleat psychobiologist', in Elliott M Blass (ed.), The psychobiology of Curt Richter, Baltimore, York Press, 1976, pp. xv-xxviii. Relevant work by Richter includes 'A behavioristic study of the activity of the rat', Comparative Psychology Monographs, 1922, 1: 1-55; 'Some observations on the self-stimulation habits of young wild animals', Archives of Neurology and Psychiatry, 1925, 13: 724-8; 'Animal behavior and internal drives', Quarterly Review of Biology, 1927, 2: 307-43; 'The electrical skin resistance', Archives of Neurology and Psychiatry, 1928, 19: 488-508; 'The grasping reflex in the new-born monkey', Archives of Neurology and Psychiatry, 1931, 26: 784-90; 'The grasp reflex of the new-born infant', American Journal of the Diseases of Childhood, 1934, 48: 327-32; 'Cyclic manifestations
}

in the sleep curves of psychotic patients', Archives of Neurology and Psychiatry, 1934, 31: 149-51;

'Increased salt appetite in adrenalectomized rats', American Journal of Physiology, 1936, 115: 155-61; 'Total self-regulatory functions in animals and human beings', Harvey Lectures, 1942-1943, series 38, pp. 63-103; 'The use of the wild Norway rat for psychiatric research', Journal of Nervous and Mental Diseases, 1949, 110: pp. 379-86; 'Diurnal cycles of man and animals', Science, 1958, 128: 1147-48; 'The phenomenon of unexplained sudden death in animals and man', in Physiological Bases of Psychiatry compiled and edited by W Horsley Gantt, Springfield, IL, Thomas, 1958, pp. 302-13 (paper read at the twenty-fifth anniversary of the Pavlovian Laboratory, Phipps Psychiatric Clinic, Johns Hopkins Hospital); 'Biological clocks in medicine and psychiatry: shockphase hypothesis', Proceedings of the National Academy of Science, 1960, 46: 1506-30; Biological clocks in medicine and psychiatry, Springfield, IL, Thomas, 1965. 


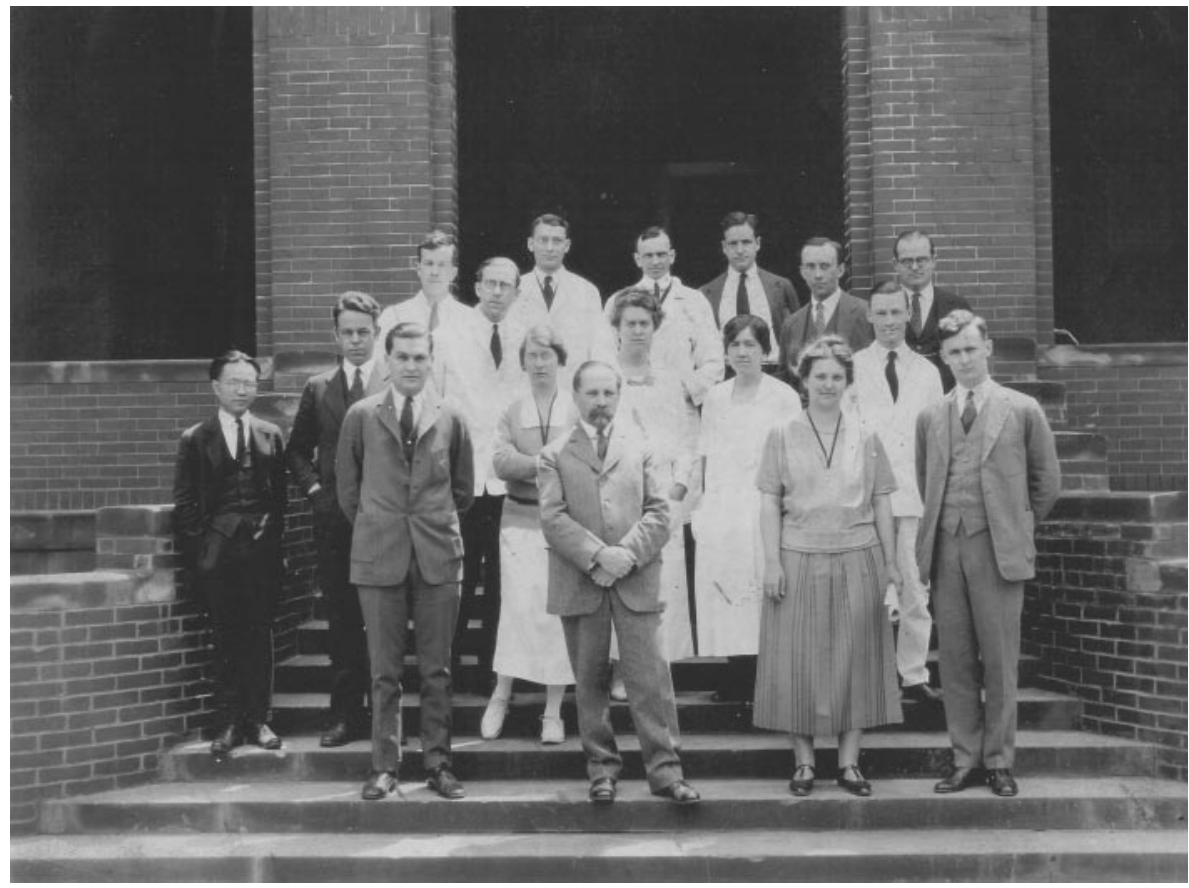

Figure 5: The staff of the Phipps Clinic in the mid-1920s. Phyllis Greenacre is on the front step, positioned next to Adolf Meyer. Curt Richter is standing almost as far from her as possible, the second figure from the left in the second row. (Reproduced by courtesy of the Alan Mason Chesney Medical Archives, Johns Hopkins Medical Institutions.)

deeply in their work, which kept them apart and in the short term reduced the opportunity to fight. But inevitably this course of action only further weakened the ties between them.

Generally shy and reserved, and diffident about promoting herself, Greenacre none the less made several efforts to alleviate the financial difficulties they faced, and to confront the frustrations she was experiencing in her professional life. On the first such occasion, she complained to Meyer: "I find myself right now in a situation where I am neither consulted nor usually even informed of those few clinic arrangements which do concern me and my work." He had chosen to restrict her opportunities mostly to the laboratory, but even here, her position as head of the laboratory needed clarification, and she informed him that she would like to expand her role working with students in this setting. Making matters worse, "I think I am alone in the clinic in maintaining in the sixth year the same official rank that I achieved automatically when I was accepted as an interne." Since her official title was "the only available index [of her standing available] to strangers and students", the situation was, to understate the matter, "occasionally embarrassing". Meanwhile, she was forced to endure the spectacle of others around her "advancing by flattery, glittering talk, obsequiousness, and insincerity, too often with 


\section{The Careers of Adolf Meyer, Phyllis Greenacre, and Curt Richter}

deliberate falsifications and distortions of the facts"-experiences to which she reacted with "discomfort and revulsion [and] disillusionment". 45

It is perhaps a measure of the strength of the ties between Greenacre and her superior that she was emboldened to send this letter to him. She insisted: "I do not wish to present these matters as grievances or demands [which is, of course, exactly what they were] but as more or less imperative factors in my work and interests." By way of justifying her actions she invoked his own teachings: "My years at the clinic have taught me the necessity of getting dissatisfactions cleared up and talked out rather than storing up for a cumulative explosion... . such an accumulation is taking place" One possible solution to her financial difficulties, she proposed, might be an increase in her clinical responsibilities. Here, perhaps, she undermined her own case by conceding that she made this proposal "as a means to increase my income rather than [from] any deeply rooted ambition. But as a practical means of easing urgent financial needs, I should welcome it". Listing her income since arriving at Hopkins in 1916, she stressed that "the apparent increase in salary during the last 2-3 years has not been a real one, amounting to no gain in actual cash at all over the year 1919-1920." It was an impossible state of affairs. An increased salary "is an urgent need for me, and one which must have just now a governing influence on my plans. The present struggle is one which I cannot keep up and [I] must find some way of relieving". ${ }^{46}$ But nothing changed.

Seven months later, she was worrying that a new title "Associate in Clinical Psychiatry" was one reserved "for people who were not full time". Once more she expressed eagerness "if possible to have the privilege of practicing this year both because it would give me certain active contacts with patients which I am now missing, and because of the possible financial help". ${ }^{47}$ Again, she was left unsatisfied.

Two years later, her situation had still not improved. Once more she appealed to Meyer, asking him to intervene with the Hopkins trustees to obtain an increased salary for her. After several weeks of ominous silence, he wrote back to her just as he left for Santa Barbara for a lucrative consultation on the state of Stanley McCormick, heir to the International Harvester fortune. ${ }^{48}$ "I certainly owe you an apology", he began, "for this long delay in answering your letter. If I had anything pleasant or favorable to report to you, I should feel better about it." But the word from the treasurer's office was "to the effect, that the University owed you nothing ... I hardly know what the next step should be". 49

Greenacre's response to this ostentatious wringing of hands was swift and fierce. She began with what, reading between the lines, was an implied threat to leave, informing Meyer that she had recently turned down a "position offered me by the National Committee for Mental Hygiene". For the present, "There are certain concrete problems which

\footnotetext{
${ }^{45}$ Greenacre to Meyer, 5 Jan. 1922, Meyer

Papers, CAJH Series XV.

${ }^{46}$ Ibid.

${ }^{47}$ Greenacre to Meyer, 22 Aug. 1922, Meyer Papers, CAJH Series XV.

${ }^{48}$ Stanley McCormick had had a psychotic breakdown some months after his marriage. Diagnosed as a paranoid schizophrenic, he was to
}

\author{
remain confined for the rest of his life, much of the \\ time in a family mansion in California. Meyer had \\ first been consulted on the case in 1906. For him, and \\ for several other psychiatrists, McCormick provided \\ the opportunity for an almost endless stream of \\ lucrative consultations stretching over four decades. \\ ${ }^{49}$ Meyer to Greenacre, 24 July 1924, Meyer \\ Papers, CAJH Series XV.
}


I have started [at Hopkins] which I feel I must finish." But her commitment was not open-ended. "I should not wish to continue, however, unless I can foresee greater development and more contacts through publication and especially through teaching, than have yet seemed to come to me." And once more she returned to the issue of her inadequate salary: "I have just received the annual appointment notice from the President's office, and find myself officially reappointed as an associate in psychiatry with a salary of $\$ 2,500$ [ $\$ 700$ more than she had made in 1921-22]. I did not know whether in the event of my return to the clinic, this was intended to constitute the whole of the salary. I should find that extremely difficult, as I think you will understand."50

Meyer does seem to have understood-understood at last that he was in grave danger of losing one of his closest and most valued associates. In San Francisco, he drafted a lengthy response to her memorandum, one that contained a remarkable set of concessions to his junior when one recalls his strong sense of hierarchy and his usual role as the bully rather than the bullied. First, he promised to meet her complaints about teaching and publication. He would set in motion a plan for her to take "every other Thursday for a topic of clinical discussion, or a series of Thursdays if you prefer". He would also "arrange with Dr Richards a certain amount of group teaching". These alterations would form part of a general "readjustment ... in which the aims of research and teaching of both yourself and the clinic come to best fruition". And he acknowledged the need to ensure that "the problem of publication is adjusted (which is my first concern)". That would remove "a cause of grievance ... which I regret very much". 51

There remained the crucial issue of her financial compensation. He announced that he could do little about the Hopkins salary. Somewhat feebly, he assured her that "concerning the sex studies, the same amount of money will be available as last year.",52 But, as if conscious that he had to offer more on this front, he made a fateful proposal, one that would have important consequences for himself, for Greenacre, and for Richter.

Another of Meyer's protégés dating all the way back to his days at Worcester, Henry Cotton, had been appointed as the superintendent of the New Jersey State Hospital at Trenton in 1907, in large part because of Meyer's firm recommendation. Beginning in 1916, Cotton had put forth the bold hypothesis that mental symptoms were epiphenomenal, and that the singular source of mental illness was the impact of chronic, undiagnosed and untreated infections in the body, infections that produced toxins that poisoned the brain. His preferred solution was surgical extirpation of the offending organs: teeth, tonsils, spleens, stomachs, colons, uteri, and so forth-operations that, so he claimed, led to cure rates exceeding 80 per cent. Invited to give the prestigious Vanuxem lecture series at Princeton University, Cotton had secured a typically ambiguous but largely favourable foreword from Meyer for the published version of the lectures. ${ }^{53}$

\footnotetext{
${ }^{50}$ Greenacre to Meyer, 18 July 1924, Meyer Papers, CAJH Series XV, emphases in the original.

${ }^{51}$ Meyer to Greenacre, 29 July 1924, Meyer Papers, CAJH Series XV. A notation on this document indicates that it was "not sent". It does serve as an indicator, however, of Meyer's worries in the face of Greenacre's mounting unhappiness about her stalled career, and it seems likely that an alternate version of this document was dispatched back to
}

\footnotetext{
Greenacre, for a key proposal made later in this draft was implemented a few weeks later.

${ }^{52}$ Ibid. For a detailed examination of the entire focal sepsis episode, see Andrew Scull, Madhouse: a tragic tale of megalomania and modern medicine, New Haven and London, Yale University Press, 2005.

${ }^{53}$ Henry A Cotton, The defective, delinquent, and insane, Princeton University Press, 1921.
} 


\section{The Careers of Adolf Meyer, Phyllis Greenacre, and Curt Richter}

But Meyer's apparent endorsement had not proved sufficient to head off a bitter professional controversy over Cotton's claims. Though the Trenton superintendent had attracted powerful support among some American and British psychiatrists, others, particularly in North America, had sharply questioned his results, with major debates over his focal sepsis theory at both the 1922 and 1923 meetings of the American MedicoPsychological Association (now the American Psychiatric Association). Fearing a hostile outside inquiry into Cotton's work, the Trenton asylum board of governors had decided to institute an assessment of its own, and had approached Meyer to ask him to undertake the task- a curious choice given that Meyer was Cotton's mentor and the godfather of his second son Adolph.

It was this Trenton work that Meyer now offered to Greenacre. Working under his supervision, the plan was for her to be seconded for two or three days each week to conduct an independent review of Cotton's methods and results. For Greenacre, the attractions were obvious: a generous supplement to her income (one that almost doubled her salary), to be paid by the New Jersey authorities; and the opportunity to publish the results of her researches into a topic that was attracting enormous professional and public attention. Meyer reminded her that the study would require her to spend considerable amounts of time away from her husband and children, for the amount of information to be gathered was considerable-but then so was the potential importance of her findings for the profession. ${ }^{54}$ For Greenacre, the decision was easy.

The work, however, turned out to be hard, taking almost eighteen months to complete. Meticulously documented, and reflecting many hours in the field, Greenacre's findings delivered an apparently fatal blow to Cotton's claims. So far from increasing cures, she found that Cotton's treatments were actively harmful, often fatal. Supported by four volumes of case notes, her report concluded that "the lowest recovery rate and the highest death rate occurs among the functional cases who have been thoroughly treated ... the least treatment was found in the recovered cases and the most thorough treatment in the unimproved and dead groups ... thorough treatment, including abdominal operation, is not only dangerous to life, but ineffective in the cases of those who survive." 55 Thousands of patients, it would transpire, had been maimed by Cotton's operations, and hundreds had died.

Cotton's reaction, when he, Meyer, and Greenacre met in Baltimore in January 1926 to discuss her findings, was to reject them out of hand. Furious, he accused her of bias against him and refused to accept any hint of criticism. Meyer for the most part sat passively by in the face of Cotton's attempts to bully Greenacre, and when the meeting ended abruptly, with Cotton leaving for Trenton, he forbade her to disseminate her findings, until such time as the two sides could reach common ground. Meanwhile, the hospital board at Trenton sided with its superintendent.

At first, Meyer's reluctance to take action appeared to be a temporizing move, but as the months went by, Greenacre increasingly came to the realization that nothing would

\footnotetext{
${ }^{54}$ Meyer to Greenacre, 22 July 1924, Meyer Papers, CAJH Series XV; Meyer to Cotton, 11 Sept. 1924, Meyer Papers, CAJH Series I/767/24; Andrew Scull, interview with Phyllis Greenacre, New York, 22 Dec.1983.
}

\footnotetext{
${ }^{55}$ Phyllis Greenacre, 'Trenton State Hospital Survey, 1924-1926', unpublished typescript, pp. 16, $20-4$, emphasis in the original.
} 


\section{Andrew Scull and Jay Schulkin}

be done to stop Cotton's experiments, and that she stood little or no chance of publishing her findings - unless she was willing to commit professional suicide by disobeying her superior. As with her earlier work on syphilis, but in this case with the additional burden of knowing of the deaths and damage that inaction was producing, Greenacre had been blocked from going into print by Meyer. For the next year and a half, she periodically pressed her superior for a change of heart, but with no success. Meanwhile, she learned that Cotton was continuing to operate on his patients, and had journeyed to Britain, where he had been lionized by leading members of the medical profession as psychiatry's Lister.

Adding to the personal pressure, the prolonged absences Greenacre's work had necessarily entailed had put further strains on a marriage that was already in deep trouble. It cannot have helped that Richter, too, had found ways to disappear from Baltimore, sometimes for extended periods. In 1924 and 1925, for example, with Meyer's support and encouragement, he spent several months at a field station in Panama, where he extended his work with sloths and other mammals. ${ }^{56}$ Mutually alienated, Greenacre and Richter were by this point essentially living separate lives. And yet when she finally discovered that her husband was having an affair with a young woman she had considered a family friend, Greenacre was devastated. It was a crushing blow to her self-esteem, leaving her unable to sleep and in "vivid pain". 57

She approached Meyer with the news, and he promptly shared what he had learned with his brother Hermann: "I was absolutely bowled over when Dr. Greenacre came to tell me the tale of disaster." For years, "everyone had thought she was one of the few who had succeeded in combining scientific and professional work with homemaking" 58 Beneath the surface, however, as Greenacre would learn in the months to come, as their impending divorce turned bitter, her husband had long resented her decision to continue her academic career. Richter wrote to his mother that "I will fight her to the end", 59 and in a series of wounding letters, began to do just that. He bitterly accused her of "a lack of affection for the children as shown by her continuing in medicine", and complained of "her inability to create a home that would have attracted him". 60

Meantime, the parallel with the Watson case was uppermost in Meyer's mind, and he confided to Hermann that Richter would have to go. He hoped that he would not lose Richter's wife as well, but "I do not know whether Dr. Greenacre can or will stay". ${ }^{61}$ A month later, she told him she simply could not remain on staff, ${ }^{62}$ leaving him to lament the discomfiture her departure would cause him: "Dr. Greenacre leaves at a time when I should have had all her help." And he openly worried that she would experience another mental collapse: "I am afraid she is not going to have an easy

${ }^{56}$ See Schulkin, op. cit., note 27 above, pp. $101-8$.

${ }^{57}$ Greenacre to Meyer, 10 Sept. 1928, Meyer Papers, CAJH Series XV.

${ }^{58}$ A Meyer to H Meyer, 27 Oct. 1927, Meyer Papers, CAJH Series IV/3/237.

${ }^{59}$ Curt Richter to his mother, Marta Richter, n.d.; 3 Feb. 1930. See also Richter to his mother, 14 June
1930. Richter Papers, CAJH Series 1,

Correspondence (Family).

${ }^{60}$ Adolf Meyer, manuscript notes on Curt Richter, dated May 1928, Meyer Papers, CAJH Series XV.

${ }^{61}$ A Meyer to H Meyer, 27 Oct. 1927, Meyer Papers, CAJH Series IV/3/239.

${ }^{62}$ A Meyer to H Meyer, 17 Nov. 1927, Meyer Papers, CAJH Series IV/3/240. 
The Careers of Adolf Meyer, Phyllis Greenacre, and Curt Richter

road. She may get into the depressive condition again which she had in 1917 and 1918." 63

\section{A Bitter Separation and Its Aftermath}

Between Christmas and the New Year, Greenacre abruptly left Baltimore for New York, leaving the children briefly with Mrs Meyer till she located a place to live. Within weeks, with Meyer's assistance, she had obtained a new job in suburban White Plains, but it was "a far cry from the intensive work at the Phipps". ${ }^{64}$ She served as a staff psychiatrist at the juvenile court and department of child welfare, a dreary, low-level routine job that left her ever more dissatisfied. Making matters worse, Richter was refusing to provide any financial support for their children, informing her that since she had chosen to take them to New York, and had her own professional career and income, he regarded them as her responsibility. Betrayed by Meyer over the Cotton affair, forced to leave behind the Phipps Clinic, which "stands more in the place of familial roof to me than any other place can", ${ }^{65}$ embroiled in a poisonous break-up with her husband, and facing a grim professional future, her depression deepened, and she sought psychotherapeutic help.

Repeatedly, Greenacre also confided her troubles to Meyer, sharing with him the grievously hurtful and obdurate letters she was receiving from Richter, and seeking advice and intervention from her "Chief". Sympathy was forthcoming, but not action. In the Watson case, Meyer had intervened decisively with the Hopkins administration to ensure his departure. With Richter, he did no such thing. Though his first reaction had been that his younger colleague would have to resign, he made no move to ensure that result. On the contrary, he allowed the younger man to become still more indispensable to his enterprise, and rather bizarrely he chose to inform Greenacre of this development: "Dr. R. has evidently changed his attitude towards my courses and instead of a cold blanket, the students with whom he deals seem to fall in line with a more favorable spirit-both the $1^{\text {st }}$ and the $2^{\text {nd }}$ year classes. I do not think it is mere policy [i.e., calculation on his part]. I really feel it is the first time he has approached the teaching with a fairer spirit, and I myself seem to feel the relief in the rather heavy load I have taken on."66

By June, even to Greenacre, Meyer was confessing to some hesitancy and indecision about his own course of action: "Whether Dr. R. had best go ... is a question. I wish he wd go to Russia where he wd like to see the Pavlov lab-and stay there to prepare for another place in this country. I shd find it terribly hard to find anyone in his place just yet." ${ }^{, 67}$ And he never had to do so. The acrimony over the impending divorce between Richter and Greenacre dragged on and on, with Meyer in the middle trying feebly to broker peace between the two fiercely contending sides. ${ }^{68}$ Even when Richter submitted

\footnotetext{
${ }^{63}$ A Meyer to H Meyer, 12 Dec. 1927, Meyer Papers, CAJH Series IV/3/240.

${ }^{64}$ Greenacre to Mrs Meyer, 3 Jan.1928; Greenacre to Meyer, 17 Jan. 1928, Meyer Papers, CAJH Series $\mathrm{XV}$.

${ }^{65}$ Greenacre to Meyer, 29 Feb. 1928, Meyer Papers, CAJH Series XV.
}

\footnotetext{
${ }^{66}$ Meyer to Greenacre, 20 Feb. 1928, Meyer Papers, CAJH Series XV.

${ }^{67}$ Meyer to Greenacre, 15 June 1928, Meyer Papers, CAJH Series XV.

${ }^{68}$ Greenacre's letters to Meyer included copies of some of Richter's letters to her, as she provided him with a blow by blow account of their disputes. See
} 


\section{Andrew Scull and Jay Schulkin}

a formal resignation in 1929, Meyer allowed him to withdraw it, and the two men then reached an understanding, one that would allow them to put the whole "unfortunate" episode behind them.

On August 26, Richter wrote:

I am writing to tell you what I would like to do next year and to offer a concrete Plan which I hope will serve the purpose of helping us to arrive at a constructive working agreement and thereby bring to a close what has been for me a very unhappy period. I am glad to state at once that I should like to withdraw my resignation and assume all my old responsibilities along with others concerned with working out the course in psychobiology. The latter responsibility I assume willingly and gladly since during the summer my resistance to giving a course of this kind has largely disappeared. I feel that now I can undertake this work with confidence as well as with enthusiasm. I may also state at once that I will give you my word that I will take care of the settlement of marital difficulties and the associated complications in a way that is in harmony with your own personal wishes and the interests of the Phipps clinic. ${ }^{69}$

Almost certainly, it was not just Richter's willingness to play a vital role in Meyer's teaching programme that persuaded Meyer to keep him on. Richter's friendship with many of the leading Hopkins scientists, and the respect with which they viewed his work, with its clever instrumentation and meticulous data collection, would undoubtedly have complicated any decision to seek his dismissal. Meyer's position placed him much further up the institutional hierarchy, but he had been unable to improve his discipline's lowly rank in the intellectual pecking order, and his wordy pronouncements were rightly seen as programmatic rather than scientific. There were signs that his colleagues were seeing an emperor bereft of clothes. On one notorious occasion, the medical students put on a play with the bearded "Meyer" as a central character, giving a lecture in Chinese, interspersed with favourite bits of Meyerian jargon: integration concept, family formation, experiment of nature, the ergasias, and so forth. Unlike his colleagues, the great man was not amused, and he induced the Medical Board to ban all future performances of the kind. ${ }^{70}$ Richter's work, in this context, provided vital evidence for the scientific fruitfulness of Meyer's concept of psychobiology. Meyer's puritanical instincts notwithstanding, Richter in all respects may have been simply too valuable to dismiss.

We do know that Meyer felt guilty about his treatment of Phyllis Greenacre. Both Phyllis Greenacre and her son, Peter Richter, commented separately that his efforts on her behalf in the 1930s reflected a sense of guilt and obligation. ${ }^{71}$ Such sentiments are

Greenacre to Meyer, 17 Jan. 1928; 29 Feb. 1928; 6 March 1928; 17 April 1928; 15 May 1928; 10 and 19 Sept. 1928; 2 and 25 October 1928; 3 (telegram) and 20 June 1929; 18 and 21 June 1920. Richter to Greenacre, 23 Aug. 1928 and Greenacre to Richter, 13 Sept. 1928, all in Meyer Papers, CAJH Series XV. There were a number of meetings between Greenacre and Meyer about these matters, and at least one three way meeting at which Meyer sought to bring matters to a conclusion.

${ }^{69}$ Richter to Meyer, 26 Aug. 1929, Meyer Papers Series XVI.

${ }^{70}$ Turner, op. cit., note 18 above, pp. 268 (where he attributes the Chinese lecture story to Richter), pp. 441-4; Bertram N Bernheim, Story of the Johns Hopkins, New York, McGraw-Hill, 1948, ch. 13.

Then there is the deafening silence about Meyer in A McGehee Harvey's Adventures in medical research, Baltimore, Johns Hopkins University Press, 1976, a lengthy hymn of praise to all the medical breakthroughs pioneered at the University.

${ }^{71}$ Phyllis Greenacre articulated this sentiment in interviews with both Andrew Scull (interview in New York City, 22 Dec. 1983) and Ruth Leys

('Impressions of my evening with Phyllis Greenacre', 16 June 1982), and without being aware of his mother's comments, Peter Richter made the same 
also evident in his private notes to himself. Some time in the summer of 1928, he wrote self-reproachfully about his behaviour towards her. For all her ability and experience, and the invaluable work she had done for him, he had neglected to advance her over the years, so that both her title and her income had lagged far behind her responsibilities. "Dr. Greenacre should have been ... instructor and director of the lab ... Justly or unjustly, I considered her as a potential rather than a fully active member of the staff, on account of the family responsibilities."72

He tried to make amends, sometimes ham-handedly. Only two months after Greenacre's abrupt departure for New York, he invited her back for a reunion of the Phipps Clinic staff. ${ }^{73}$ Still traumatized, she responded: "I want if possible to attend, for the Phipps will always have my loyalty and interest ... [But] I do not know whether I shall find it possible to face again, in the setting of a family reunion, the whole physical situation which swamps me with such painful conflicts and memories ... the thought of this past year and a half gives me a comprehensive shudder." ${ }^{74}$ Six weeks later, she had made up her mind: "There is much that draws me and I should like to come. But I have about decided not to attempt it, because it still stirs me up too much,- - and in addition I do not know that I should really be able to live up to the conventional surface demanded ... I do not want to take the risk of exposing my personal feelings in a general gathering of that kind.",75

In mid-June, Meyer had an even more audacious proposal to make to her: he was setting up a new research project on schizophrenia. Would she return to direct it? He knew she had expressed an interest in "practice with patients whom you can treat according to emergency, outside of hospital ... [and] were inclined to make any special research and teaching incidental to practice. The research position I can offer naturally assumes a somewhat different orientation", but he was convinced it could be "an ideal position for you". "Now it is just a question whether such leadership in handling the material appeals to you and whether it would help you overcome preoccupations of memories of the past." 76

The proposal was, from Greenacre's perspective, impossible to accept, even though Meyer had assured her that he had arranged for the departure of Richter's mistress before she would need to arrive in Baltimore, and had emphasized that "I am terribly anxious to make possible a harmonious active working group during the rest of my working years at Hopkins."77 Though her New York situation was an unhappy one, "I find that going back there [to Baltimore] even for a short time, precipitates a depression that takes several weeks to deal with. I know that ultimately I will come to a better immunization, but it seems to be a bewilderingly slow process ... In addition, I would hesitate before taking the children back now into an atmosphere in which there would be the possibility of stirring up further conflict for them. They accept Curt's not living with us now, - as

point in an interview with Andrew Scull, 15 Aug. 1996.

${ }^{72}$ Manuscript note about Phyllis

Greenacre, undated [1928], Meyer Papers, CAJH Series XV.

${ }^{73}$ Meyer to Greenacre, 20 Feb. 1928, Meyer Papers, CAJH Series XV.

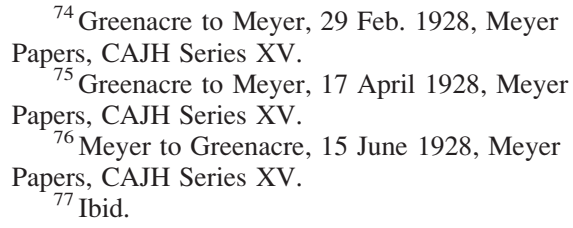




\section{Andrew Scull and Jay Schulkin}

we are on new ground, but they think that if we went back to Baltimore, it would mean a re-establishment of joint family life." 78

In her New York exile, Greenacre set about rebuilding her life and career. To deal with her depression, she began psychoanalytic treatment, first with the Jungian analyst, Beatrice Hinkle, and then with Freud's first biographer, Fritz Wittels, ${ }^{79}$ and lastly with Edith Jacobson. ${ }^{80}$ Beyond whatever therapeutic value these encounters may have had in troubled times, they gave her insight into a new intellectual universe, and ultimately launched her on a radically different career path. As she began to recover some semblance of stability in her life, the endless round of mundane activities that her job at the juvenile court entailed increasingly left her feeling trapped. It had been "something I could carry ... adequately even through a period of intense personal preoccupation." Three years on, however, she lamented that her position "furnishes relatively little opportunity for developement $[\mathrm{sic}]$ and I do not feel that I can stick by it indefinitely without danger of atrophy". 81

Hence came a renewed appeal to Meyer: "Since you know my capacities and limitations better than anyone else, I would appreciate very much your advice and help if you know of any opening which I might satisfactorily fill. ${ }^{82}$ For months, little help was forthcoming. Meyer did suggest that she approach some prominent New York psychiatrists-William L Russell, David Wells, George Stevenson-to see if they knew of a position for her. More than a year later, he at last intervened more forcefully, and secured her a post as director of outpatient psychiatric treatment at the Cornell Medical Center in New York. "I am ever so grateful," ${ }^{83}$ Greenacre informed him. She had at last obtained a new academic appointment, almost four years after her abrupt departure from Hopkins.

Greenacre's new role overseeing the treatment of patients not confined in a mental hospital now provided the material basis on which she rebuilt her career along novel lines. Her second analyst, Fritz Wittels, was a powerful figure in the oldest and most important Freudian centre in the United States, the New York Psychoanalytic Society. Within a few months of the society deciding to set up a formal programme of psychoanalytic education, Greenacre joined the Institute as a candidate, and by 1937, to Meyer's considerable dismay, she had begun to practice as an analyst. ${ }^{84}$

Thereafter, her rise was rapid and remarkable, if somewhat surprising. The Society and its companion Institute were dominated, by the late 1930s, by an oligarchy of European refugees who had fled the Nazis. These exiles, for the most part, exhibited a

\footnotetext{
${ }^{78}$ Greenacre to Meyer, 10 Sept. 1928, Meyer Papers, CAJH Series XV.

${ }^{79}$ See Fritz Wittels, Freud and his time, New York, Liveright, 1931.

${ }^{80}$ The sessions with Jacobson went very badly, and Greenacre finally terminated the analysis. Peter Richter, interview with Andrew Scull, 4 Feb. 1996.

${ }^{81}$ Greenacre to Meyer, 13 Dec. 1930, Meyer

Papers, CAJH Series XV.

82 Ibid.

${ }^{83}$ Greenacre to Meyer, 18 Sept. 1931, Meyer Papers, CAJH Series XV. When she had left Baltimore, Greenacre asserted many years later, Meyer "told her at that time that he had not treated
}

her correctly. She felt that this was true, and that he would therefore do anything for her." Ruth Leys,

'Impressions of my evening with Phyllis Greenacre', 16 June 1982

${ }^{84}$ Greenacre commented at length about Meyer's dismay at her embrace of Freud, of whom he became increasingly critical (and jealous) in the later stages of his own career, in her interviews with Ruth Leys (16 June 1982) and Andrew Scull (22 Dec. 1983), and noted that a number of Meyer's most talented students had emulated her. For discussions of Meyer's complicated relationship with Freud and psychoanalysis, see Leys, op. cit., note 17 above; and Hale, Jr, op. cit., note 17 above, esp. pp. 168-72. 
barely concealed contempt for American analysts, and tended to keep power firmly in their own hands. ${ }^{85}$ Virtually alone among her native-born contemporaries, Greenacre succeeded in penetrating this inner circle of Viennese exiles (many of them Freud's intimates). As early as 1942, she was granted the coveted status of training analyst and became a member of the society's Education Committee. These were critical steps in her new career. "Being a training analyst conferred great prestige within the organization, as well as referrals, economic security, and the mystique of authority." 86

By the 1950s, Greenacre was training more analysts than anyone else at the Institute. Her status had been recognized by her election, first as President of the Institute, from 1948 to 1950, and then as President of the Society itself, half a dozen years later. And she became "the analyst of analysts, particularly those who were troubled". ${ }^{87}$ Leaving her Meyerian training far behind, she became an expert on the psychoanalytic study of childhood and adolescence, ${ }^{88}$ and wrote psychohistorical studies of such figures as Jonathan Swift, Lewis Carroll, and Charles Darwin. ${ }^{89}$

Between the end of the Second World War and the late 1960s, psychoanalysis temporarily dominated American psychiatry. During the quarter century of Freudian hegemony, the New York Psychoanalytic Society and Institute was without question one of the most prestigious centres of Freudian ideas and training in the country-what one writer termed "the Harvard of American analysis". 90 Greenacre's leading position in its councils thus made her arguably one of the most influential psychiatrists and analysts in the country. Such, indeed, was the conclusion reached by the American political scientist, Arnold Rogow, in 1970. Conducting a survey of psychiatrists, he found that Greenacre was considered the fourth most influential living analyst, ranking behind only Anna Freud, Heinz Hartmann, and Erik Erikson. ${ }^{91}$ It was a remarkable rise from the emotional turmoil and professional marginality which had confronted her in the late 1920s.

Her ex-husband had an equally stellar career, for Meyer's faith in Richter would be amply repaid over the ensuing years. His protégé's accumulating body of scientific work would lead to election to such august institutions as the National Academy of Science and the American Philosophical Society, and a serious nomination for a Nobel Prize. In a lifetime of laboratory labours, his elaboration of the significance of the biological clock and his work on homeostasis and the behavioural regulation of the internal milieu within the context of nutritional choice were of particular importance, stimulating a host of later researches.

From the late 1920s until the 1950s, Richter was at the forefront of those creating a psychology that eschewed the introspective and marginalized the human in favour of

\footnotetext{
${ }^{85}$ See, for example, John Frosch, 'The New York psychoanalytical civil war', J. Am. Psychoanal. Assoc., 1991, 39: 1037-64.

${ }^{86}$ David James Fisher, review of Douglas Kirsner, Unfree associations, American Imago, 2002, 59: 209-23, quotation on p. 213.

${ }^{87}$ Manuel Furer, quoted in Douglas Kirsner, Unfree associations: inside psychoanalytic institutes, London, Process Press, 2000, p. 27.

${ }^{88}$ See, for example, Phyllis Greenacre, Trauma, growth, and personality, New York, Norton, 1952.
}

\footnotetext{
${ }^{89}$ Phyllis Greenacre, Swift and Carroll, New York, International Universities Press, 1955; idem, The quest for the father: a study of the Darwin-Butler controversy as a contribution to the understanding of the creative individual, New York, International Universities Press, 1963.

${ }^{90}$ Fisher, op. cit., note 86 above, p. 212.

${ }^{91}$ Arnold A Rogow, The psychiatrists, New York, Putnam, 1970, p. 109. Greenacre was the highest ranking analyst who was not either a European, or a European refugee.
} 


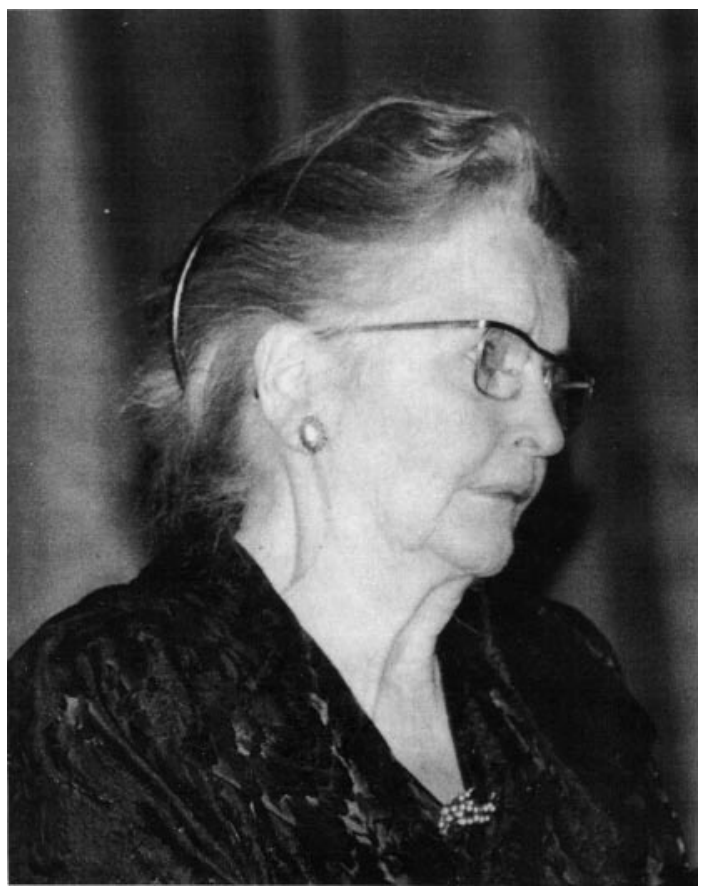

Figure 6: Phyllis Greenacre lecturing during her New York years, most probably during the 1960s. (Courtesy of the New York Psychoanalytic Institute and Society Archive.)

experimental studies of the psychobiology of laboratory animals - the very antithesis of the intellectual approach his ex-wife was embracing and advancing. Over and over again, he sought ways to take the body apart and put it together again, honing his surgical skills, creating new instruments, constructing novel experiments to examine behavioural and biological adaptation. Even his formal retirement in the late 1950s brought no let-up in his work. To the very end of his life, and to the evident dismay of the university, which found itself unable to eject so distinguished a scientist from his laboratory (even turning off the heat did not dissuade him from remaining in situ), Richter continued to occupy his space in the Phipps Clinic, turning out papers on growth hormone and cortisol secretion in rats, guinea pigs, and monkeys in his seventh decade on the staff, even as the rest of the building was torn apart and renovated around him.

\section{Conclusion}

This paper has examined some aspects of the development of American psychiatry, psychoanalysis, and psychobiology through the prism of three overlapping and interlocking lives and scientific careers. Adolf Meyer, the most senior of the three, played a vital but ambiguous role in the development of his two protégés. It was his recognition of their talents and the environment that he created at the Phipps that allowed Phyllis Greenacre and Curt Richter to manage the crucial transition from promising student to established 


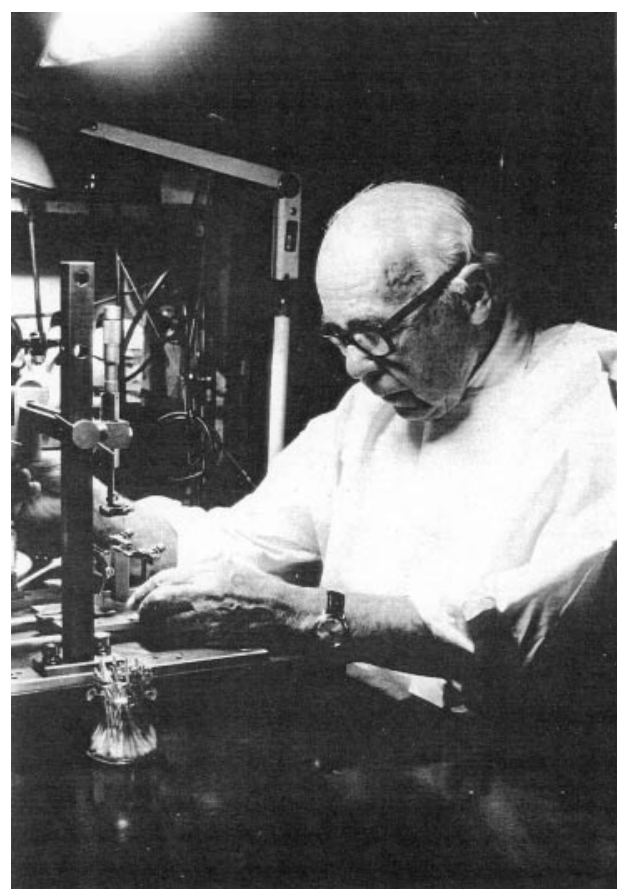

Figure 7: Curt Richter at his microscope (1976). (Reproduced by courtesy of the Alan Mason Chesney Medical Archives, Johns Hopkins Medical Institutions.)

professional. A notoriously controlling figure, Meyer for more than a decade played a large role even in the personal lives of his two associates, a role that was all the more expansive, perhaps, because Greenacre was thoroughly estranged from her parents and, at more than one time in her Hopkins career, emotionally vulnerable; and because Richter had lost his father as a young child.

Yet Meyer held back, as well as advanced, Greenacre's career. He encouraged her early researches into the neurobiology of syphilis, and then stood in the way of her publishing her results. He constrained her opportunities for clinical work, and failed to advance her in rank or salary, even as her experience grew and her value to his enterprise soared. (Latterly, even he would concede that this might have reflected an unconscious prejudice against a female associate who remained ambitious to develop her career alongside marriage and motherhood.) He prevailed on her to invest eighteen months of her career investigating the experimental treatments of another of his protégés, Henry Cotton, and then suppressed her findings, placing her in an almost impossible ethical dilemma. $^{92}$ (The bigger price in this instance, of course, was paid by yet more mental

\footnotetext{
${ }^{92}$ In other contexts, Nathan Hale, Jr has spoken of Meyer's "personal failings ... notably his ambivalence and paralyzing caution" (op. cit., note 17 above, p. 168); and Ruth Leys of his dislike of "conflict and contention of any kind" and "an
}

intellectual timidity that all too often ... made him incapable of acting decisively when controversial matters were at stake." (Leys, op. cit., note 17 above, p. 451.) For her part, Phyllis Greenacre adduced his horror of airing dirty professional laundry in public, 


\section{Andrew Scull and Jay Schulkin}

patients who found themselves subjected to maiming, even fatal rounds of surgery, while Meyer remained silent and complicit in Baltimore.) And he allowed, perhaps indirectly forced, her departure from Hopkins and Baltimore when, having been informed of Richter's sexual indiscretions, he kept her husband on the staff, creating an impossible environment for Greenacre.

Unintentionally, of course, Greenacre's forced flight to New York, and the emotional turmoil associated with it, paved the way for her intellectual transformation from a Meyerian to a Freudian psychiatrist. Her success here coincided with the emergence of psychoanalysis as the dominant strand in American psychiatry, and helped to catapult her to the highest reaches of her chosen profession. Obviously, the very qualities that had marked her time at Hopkins - her intellectual acumen, her capacity for hard work, her discretion, her curiosity - did much to foster her advancement even in the peculiar environment that was New York psychoanalysis, where she became one of the few figures who was not a Middle European refugee and a Jew to advance into the inner circle of analysts.

Greenacre professed a continuing gratitude to Meyer for the training he had provided, but it was a gratitude increasingly tempered by a sense of the limitations of his world view. As she acknowledged late on in her career, "the training to observe [she had received at his hands] has been of incalculable benefit to me and I owe a debt of gratitude for it". But by then, she had distanced herself from "an obsessional and probably futile search for accuracy" and had long reached the conclusion that "the emphasis on recording all possible phenomenological details" about the patient's life history had "sometimes reached fantastic proportions". Not the least part of what she had taken from her Hopkins' experience was thus a negative lesson, "the warning not to drive recording observation to a stage of the infinite and the absurd in the effort to cover everything". 93

For Meyer, indeed, nothing had been too trivial or inconsequential to record and to enter on a patient's life chart. ${ }^{94}$ "A fact", he proclaimed, "is anything which makes a difference." 95 But his system advanced no clear criteria for determining what did make a difference. By contrast (and one suspects that the transition was no accident) in becoming an orthodox Freudian, Greenacre had moved from this sort of catholic eclecticism, where interpretation was loose, unstructured, and lacking any way of discovering what was aetiologically significant, to a highly deterministic intellectual system that was in many ways its polar opposite.

If Greenacre's success after she left Hopkins was the more remarkable because it was done in the face of such obstacles - her gender, her national origin, the sharp shift in intellectual focus and identity that it required-her former husband's progress is in some ways less remarkable, even if he achieved a comparable level of distinction in his chosen field. Curt Richter had no gender handicaps to overcome. He remained in

and his loyalty to the weakest of his disciples as possible spurs to silence. (Interview with Andrew Scull, 22 Dec. 1983.) All these factors may help us understand Meyer's behaviour. None of them, it goes without saying, excuses it.

${ }^{93}$ Phyllis Greenacre, Emotional growth, New York, International University Press, 1971, p. xxii.

${ }^{94}$ For a discussion of Meyer's invention of the "life chart" and its relationship to his psychiatry, see
Ruth Leys, 'Types of one: Adolf Meyer's life chart and the representation of individuality', Representations, Spring 1991, 34: 1-28.

${ }^{95}$ Adolf Meyer, 'The scope and teaching of psychobiology', in Alfred Lief (ed.), The commonsense psychiatry of Dr. Adolf Meyer, New York, McGraw-Hill, 1948, p. 436. 
the environment which had first nurtured his scientific career, and could build cumulatively on the foundations he had created during the 1920s. His extraordinary usefulness to Meyer had ensured his initial survival beyond the crisis that had emerged with the exposure of his affair, and his creativity and ingenuity as an experimentalist, his drive and compulsion to work make the accomplishments of his later years somewhat unsurprising, if none the less notable. His and Meyer's relationship was, in part, a "marriage" of convenience more than anything else, with the older man benefiting indirectly from the prestige that Richter's laboratory brought to the field of psychobiology, but contributing very little of a concrete sort to the enterprise.

Not surprisingly, Richter's career continued to flourish in the decades after Meyer's retirement. Indeed, he and Greenacre were professionally active almost to the end of remarkably long lives. Born in the same year, 1894, both died within the space of less than ten months, Richter in December 1988, and Greenacre in October the following year.

Having both lived for almost a century, Richter and Greenacre had grown up in a world that was unfriendly, even hostile, to the idea of women having active careers in science and academic medicine, most especially if they further tempted fate by presuming to marry and have children. Their own marriage had foundered under the attendant strains. After their partnership broke apart, Richter remarried, and had another child by a wife content to play the supportive female role then prescribed by the culture. Greenacre, by contrast, eschewed further matrimonial entanglements, refused to rein in her ambitions, and overcame the powerful obstacles presented by her status as a woman and a single parent to build a life of remarkable professional accomplishment. In the process, she helped to create a world of very different norms and structural possibilities for the generation coming to maturity at her death—albeit one not immune, of course, to its own inequalities and prejudices.

Meyer's position at the forefront of American psychiatry was in substantial part the product of his strategically important post as professor at Hopkins, at a time when it was almost certainly the premier medical school in the United States. His resistance to the schemes promoted by the Rockefeller Foundation to have medical school faculty appointed to full-time salaried positions (rather than subsisting on clinical income) ${ }^{96}$ left him bereft of the generous funding more compliant departments received from Rockefeller's General Education Board, and though he trained a whole generation of leading American psychiatrists (and developed techniques like the life chart which provided some structure to the practice of psychiatry), it was his institutional location, rather than the power of his ideas, which made him so central to what remained at his death a marginal and stigmatized specialty. Hence, perhaps, his depressed musings, in characteristically un-idiomatic prose, just three years before his death: "What was it that failed to go across? Did I pussyfoot too much? Wherein did I fail?"97 And hence as well the evanescence of his influence, once he had passed from the scene.

\footnotetext{
${ }^{96}$ On the Rockefeller initiative, see Donald Fleming, 'The full time controversy', J. Med. Educ., 1955, 30: 398-406. Harvey Cushing, the pioneering neurosurgeon, was another prominent medical academic who objected fiercely to the Rockefeller proposals.
}

\footnotetext{
${ }^{97}$ Adolf Meyer, 20 Nov. 1947, Meyer papers, CAJH Series VI/8, quoted in Hale, Jr, op. cit., note 17 above, pp. 167-8.
} 


\section{Andrew Scull and Jay Schulkin}

Curt Richter's career might well have been cut short by his extramarital affair. After all, something very similar had cost his patron, John Watson, both his Hopkins post and any future in academia; and one of Watson's predecessors as a professor of psychology, James Mark Baldwin, had likewise been forced to resign his Hopkins post in 1908 , when he was caught in a black brothel raided by the police. ${ }^{98}$ Meyer had supported both earlier dismissals, ${ }^{99}$ but, as we have shown above, in Richter's case he prevaricated and then let his subordinate remain. Deviance that in two cases spelled professional ruin was ignored for someone of such central importance to the Meyerian project. It was Richter's talents, though, that let him escape from Meyer's shadow, and to go on to develop a distinguished and independent scientific career. But that career extended into the era of big science and a bureaucratic, peer-reviewed grant process, an environment for which the independent and idiosyncratic Richter was ill-suited, and of which he was increasingly critical. ${ }^{100}$ By the end of his long and illustrious scientific career, Richter too was something of an intellectual oddity, someone who left few students of his own, and one whose influence was largely indirect and often unacknowledged.

Finally, we have emphasized the gendered discrimination that marked Phyllis Greenacre's career, and that made her accomplishments the more striking. But precisely because psychiatry was so little valued by the medical profession, it was a niche in the professional division of labour that was in general more receptive than most to women. And that was even more true of psychoanalysis, where a number of female analysts besides Greenacre came to occupy positions of considerable prominence: Helene Deutsch, Karen Horney, Frieda Fromm-Reichmann, and Melanie Klein and her bitter antagonist Anna Freud, to name but a handful of obvious examples. Within American psychoanalysis, Greenacre long occupied a position of great prestige and influence at the very centre of Freudian orthodoxy, the New York Psychoanalytic Institute and Society. And in the 1950s and 1960s, while psychoanalysis occupied the commanding heights of American psychiatry, that meant she was a figure of some moment in the psychiatric profession broadly construed. But the very possibility of such a career and set of accomplishments arose out of her willingness during the $1920 \mathrm{~s}$ to be silenced; to acknowledge her subordinate state; to abide by the norms that enjoined junior researchers to acknowledge the absolute authority of their superiors; and her decision to eschew the lonely (and usually fatal) role of the whistle-blower. ${ }^{101}$ Finally, she lived long enough to see her form of science become an anachronism. The resurgence of biological psychiatry meant that the branch of the enterprise in which she had achieved prominence lost its lustre, its intellectual pre-eminence, and its appeal. Greenacre had had her analysands, but, by the late twentieth century, that scarcely seemed to matter.

\footnotetext{
${ }^{98}$ See Philip Pauly, 'Psychology at Hopkins: its rise and fall', Johns Hopkins Magazine, Dec. 1979, 30: $36-41$.

${ }^{99}$ As Ruth Leys notes in her paper on 'Meyer's dealings with Jones' (note 17 above), esp. pp. 448-50, 454-6.

${ }^{100}$ Schulkin, op. cit., note 27 above, pp. 136-7.
}

\footnotetext{
${ }^{101}$ C Fred Alford, Whistleblowers: broken lives and organizational power, Ithaca, NY, Cornell University Press, 2001; David Rothman, Strangers at the bedside, New York, Basic Books, 1991, pp. 70-84; Robert Bell, Impure science: fraud, compromise, and political influence in scientific research, New York, Wiley, 1992.
} 